\title{
Ultrastructural alterations in the liver and intestine of carp Cyprinus carpio induced orally by ultra-low doses of endosulfan
}

\author{
T. Braunbeck ${ }^{1, *}$, S. Appelbaum ${ }^{2}$ \\ ${ }^{1}$ Department of Zoology I, University of Heidelberg, Im Neuenheimer Feld 230, D-69120 Heidelberg, Germany \\ ${ }^{2}$ Aquaculture Laboratory, Ben Gurion University of the Negev, Jacob Blaustein Institute for Desert Research, \\ Sede Boqer 84990, Israel
}

\begin{abstract}
In order to elucidate the importance of food-borne chemical contamination in fish, cytological and ultrastructural alterations in hepatocytes and enterocytes of common carp Cyprinus carpio L. exposed for $5 \mathrm{wk}$ to $0.5 \mathrm{\mu g}$ endosulfan $(6,7,8,9,10,10$-hexachloro-1,5,5a,6,9a-hexahydro-6, 9methano-2, 4,3-benzo-dioxyanthiepin-3-oxide) $\mathrm{kg}^{-1}$ food dry weight, equivalent to an ultra-low dosis of $15 \mathrm{ng} \mathrm{kg^{-1 }}$ fish $\mathrm{d}^{-1}$, were investigated by means of light and electron microscopy. Observations on liver alterations were quantified by morphometric analysis. Livers show enlargement of the nucleolus, increase in number and size of both Golgi fields and rough endoplasmic reticulum (ER) lamellae, as well as proliferation of peroxisomes and lysosomes. Taken together, these alterations represent the morphological equivalent of a general stimulation of hepatic metabolism. Proliferation of the smooth ER is indicative of the onset of biotransformation processes under the influence of food-borne endosulfan. Further pathological processes in the liver were evident by glycogen and lipid depletion, invasion of phagocytic macrophages, and accumulation of myelinated bodies in endothelial cells of hepatic sinusoids. In the intestinal tract, exposure to endosulfan is associated with a complete lack of chylomicrons in the epithelial lining, which indicates disturbance of intestinal absorption. The reaction of the gut epithelium also included considerable distension of the intercellular space and an elevated number of lysosomal inclusions in enterocytes. An increased rate of mucous cell precursors was detectable, and macrophages were numerous. Results are consistent with endosulfan resorption by the intestinal epithelium and the coexistence of gut and liver ultrastructural changes at extremely low doses. Thus, the substantiation of pathological alterations in organs sequentially in contact with toxicants appears useful as a biomarker of pollutant exposure and effect. With regard to a chemical spill into the Rhine river at Basel. Switzerland, in November 1986, endosulfan, as a component of the mixture of toxic substances, may well have contributed to the overall toxicity of the chemicals released during the accident and the subsequent fish kill, less as a toxicant in itself than as a stimulant for the toxicity of other xenobiotics
\end{abstract}

KEY WORDS: Fish Endosulfan - Liver - Ultrastructure - Toxicology Sublethal effects

\section{INTRODUCTION}

The cyclodiene insecticide endosulfan $(6,7,8,9,10,10$ hexachloro-1,5,5a,6,9a-hexahydro-6,9-methano-2,4,3benzo-dioxyanthiepin-3-oxide) is among the most toxic pesticides for aquatic life, especially fish, and has, therefore, been registered as a 'priority pollutant' by the US Environmental Protection Agency (Holcombe

•E-mail: braunbeck@urz.uni-heidelberg.de et al. 1983, Janardan et al. 1984). Acute toxicity for fish $\left(\mathrm{LC}_{50}: 96 \mathrm{~h}\right)$ varies from $0.1 \mu \mathrm{g} \mathrm{l}^{-1}$ in Morone saxatilis (Korn \& Earnest 1974) and mosquito fish (Joshi et al. 1981) to 20 and $42 \mu \mathrm{g} \mathrm{l^{-1 }}$ in eel at 29 and $22^{\circ} \mathrm{C}$, respectively (Ferrando et al. 1987, 1991). For reviews on acute toxicity data of endosulfan, see Schimmel et al. (1977), Johnson \& Finley (1980), Goebel et al. (1982), Verschueren (1983), Baier et al. (1985), Mayer \& Ellersieck (1986), Paul \& Raut (1987), Sunderam et al (1992), Gimeno et al. (1994), as well as Arnold et al. $(1995,1996 a, b)$. 
Only recently, in addition to a multitude of other sublethal effects, has endocrine disruption repeatedly been demonstrated as a further adverse effect of endosulfan (Matthiessen \& Logan 1984, Inabraj \& Haider 1988, Pandey 1988, Sinha et al. 1991, Chakravorty et al. 1992, Petit et al. 1995, Bjerregaard et al. 1998).

Particularly in developing countries, endosulfan is in general use for pest control in jute, cotton, sugar cane and vegetables. Due to constant leaching as well as superficial runoff during rainfall and to accidental spillage, endosulfan has repeatedly been reported in surface waters of developing and developed countries (Herzel 1972, Van Dyk \& Greeff 1977, Wall et al. 1978, Frank et al. 1982, Baier et al. 1985). In the Dutch section of the river Rhine, mean concentrations of 0.1 to $0.3 \mu \mathrm{g} \mathrm{l}^{-1}$, with maximum values of $0.81 \mu \mathrm{g} \mathrm{l}^{-1}$ in 1969 and since then decreasing, have been reported for the period 1969 to 1975 (Wegmann \& Greve 1978). In 1969, endosulfan was causally implicated in a fish kill in the river Rhine (Greve \& Wit 1971).

During another chemical spill at Basel in November 1986, about 30 toxic chemicals including various pesticides, solvents, emulgation aids, stabilizers and other products were released into the river Rhine, leading to a fish kill of considerable dimensions (Deutsche Kommission zur Reinhaltung des Rheins 1986, Braunbeck et al. 1990a). On this occasion, 20 to $60 \mathrm{~kg}$ of endosulfan (active ingredient) were spilled resulting in water concentrations of 0.03 to $0.34 \mathrm{\mu g} \mathrm{l}^{-1}$ (Deutsche Kommission zur Reinhaltung des Rheins 1986). Since bioaccumulation factors of endosulfan in fish may reach values of $\geq 1000$ after only $96 \mathrm{~h}$ and $\geq 2000$ after 28 d (Schimmel et al. 1977, Verschueren 1983), the concentrations measured after the chemical spill in 1986 could be considered as a cause of sublethal effects in fish.

In order to determine if trace concentrations of endosulfan are taken up via contaminated food particles, as was postulated by Herzberg (1986), and to evaluate a possible involvement of endosulfan in the fish kill in the river Rhine in November 1986, juvenile common carp were exposed to food tainted with $0.5 \mu \mathrm{g} \mathrm{kg}^{-1}$ endosulfan, i.e. a level most likely reached during the chemical spill. Common carp was chosen as the test species due to its moderate sensitivity to endosulfan, the $\mathrm{LC}_{50}$-values decreasing from $7 \mu \mathrm{g} \mathrm{l}^{-1}$ after $24 \mathrm{~h}$ (Rao \& Murty 1980) to $0.9 \mathrm{\mu g} \mathrm{l}^{-1}$ after $168 \mathrm{~h}$ (Basak \& Konar 1976), thus indicating time dependence of endosulfan toxicity.

According to Basak \& Konar (1977), even endosulfan concentrations of $\geq 1.4 \mu \mathrm{g} \mathrm{l}^{-1}$ do not induce alterations in food consumption, behavior and reproduction of carp; thus, more sensitive methods had to be employed for the detection of possible sublethal effects. Cytological investigations of fish organs, especially of the liver, repeatedly proved to be an extraordinarily sensitive tool to reveal both adaptive processes and detrimental effects in fish induced by organic pollutants (Hacking et al. 1978, Hinton et al. 1978, 1985, 1987, 1988, Lipsky et al. 1978, Mc Cain et al. 1978, Klaunig et al. 1979, Schoor \& Couch 1979, Hawkes 1980, Rojik et al. 1983, Benedeczky et al. 1984, 1986, Braunbeck et al. 1989, 1990a,b,c, 1992a,b, Burkhardt-Holm et al. 1990, Braunbeck \& Völkl 1991, 1993, Braunbeck 1994). Since fish liver is regarded as a major site of storage, biotransformation and excretion of endosulfan (Schoettger 1970, Rao et al. 1980, Rao \& Murty 1982, Herzberg 1986, Arnold \& Braunbeck 1993, 1994, Arnold et al. 1995, 1996a,b), and since the intestinal tract is the first organ to come into contact with food-borne contaminants, ultrastructural changes of these organs were chosen as criteria for the sublethal action of endosulfan.

\section{MATERIALS AND METHODS}

The experiments were conducted at the Aquaculture Laboratory of The Jacob Blaustein Institute for Desert Research, Ben Gurion University of the Negev, Sede Boqer Campus, Israel.

Fish. Two-yr-old juvenile common carp Cyprinus carpio L. with an average body weight of $62.5 \mathrm{~g}$ from the laboratory stock at Sede Boqer were kept in lots of 20 fish $\left(25 \mathrm{~g} \mathrm{l}^{-1}\right.$ in glass aquaria containing $50 \mathrm{l}$ of permanently aerated water adjusted to $27 \pm 1^{\circ} \mathrm{C}\left(\mathrm{CaCO}_{3}\right.$ : $400 \pm 20 \mathrm{mg} \mathrm{l}^{-1}, \mathrm{pH}: 7.6 \pm 0.2$ ). Water was constantly replaced at a rate of $30 \mathrm{l} \mathrm{h}^{-1}$ in a flow-through system. Fish were allowed to acclimate to specific conditions for $4 \mathrm{wk}$. During the adaptation period, fish were fed $3 \mathrm{~mm}$ pellets of commercially available carp feed (30.9\% crude protein, $3.2 \%$ crude lipid, $10.3 \%$ water, $5.9 \%$ ash, $0.5 \%$ vitamin mixture; supplemented with $0.4 \mathrm{~g}$ mineral mixture) at daily rations of $3 \%$ body weight. Food was equally apportioned over the entire 16 h light phase.

Contaminant. Technical endosulfan $(6,7,8,9,10,10$ hexachloro-1,5,5a,6,9a-hexahydro-6,9-methano-2,4,3benzo-dioxyanthiepin-3-oxide; thiodan; $35 \% \mathrm{w} / \mathrm{v}$ ) was diluted to $10^{-5} \%(\mathrm{w} / \mathrm{v})$ with ethanol (pro analysis grade, p.a.). $4 \mathrm{~g}$ of mineral mixture were soaked with $5 \mathrm{ml}$ of the diluted endosulfan solution. After removal of the solvents in a rotary evaporator under vacuum at $30^{\circ} \mathrm{C}$, the endosulfan-contaminated mineral mixture was thoroughly mixed with $1 \mathrm{~kg}$ of pulverized food (resulting in a final endosulfan concentration of $5 \mu \mathrm{g}$ $\mathrm{kg}^{-1}$ food). Food was moistened with distilled water repelleted to a diameter of $3 \mathrm{~mm}$, and air-dried. Food for control carp was treated identically but without contamination with endosulfan. 
Treatment. After acclimation, fish were divided into 2 groups and exposed for $5 \mathrm{wk}$ to $0.5 \mu \mathrm{g} \mathrm{kg} \mathrm{kg}^{-1}$ foodborne endosulfan $\mathrm{d}^{-1}$ (nominal concentration; equivalent to $15 \mathrm{ng} \mathrm{kg}^{-1}$ fish $\mathrm{d}^{-1}$ ). At the end of this period, fish were sacrificed and further processed for electron microscopy.

Electron microscopy. Four control and 4 endosulfan-treated fish were fixed for electron microscopy. All manipulations were performed at midmorning to avoid diurnal variation. For fixation, fish were anaesthetized by suspension in an aqueous solution of ethyl-4-aminobenzoate (benzocaine) and perfused in situ through the ventricle, first with physiological saline containing $2 \%$ polyvinylpyrrolidone (PVP, Merck, Darmstadt, FRG) and $0.5 \%$ procaine hydrochloride (Merck) for $30 \mathrm{~s}$ to remove blood cells, followed by ice-cold $1.5 \%$ glutardialdehyde and $1.5 \%$ formaldehyde (freshly prepared from paraformaldehyde) in $0.1 \mathrm{M}$ sodium phosphate buffer ( $\mathrm{pH} 7.6$ ) containing $2.5 \%$ PVP ( 3 to $4 \mathrm{~min}$, equivalent to approx. $50 \mathrm{ml})$.

The anterior portion of the liver and small segments of intestinal regions I and II were excised immediately after perfusion, cut into small blocks of $<1$ and $2 \mathrm{~mm}$ side length (liver and intestine, respectively) and incubated in perfusion fixative for at least $30 \mathrm{~min}$ at $4^{\circ} \mathrm{C}$. The fixation was continued in $2.5 \%$ glutardialdehyde in $0.1 \mathrm{M}$ sodium cacodylate buffer ( $\mathrm{pH} 7.6$ ) containing $4 \%$ PVP and $0.05 \%$ calcium chloride for 20 min at $4^{\circ} \mathrm{C}$. After rinsing in cacodylate buffer, tissue blocks were postfixed at $4^{\circ} \mathrm{C}$ for $1 \mathrm{~h}$ with $1 \%$ osmium ferrocyanide (Karnovsky 1971).

After repeated rinsing in $0.1 \mathrm{M}$ cacodylate and $0.05 \mathrm{M}$ maleate buffers ( $\mathrm{pH} 5.2$ ), the tissue was stained en bloc with $1 \%$ uranyl acetate in maleate buffer for at least $1 \mathrm{~h}$ at $4^{\circ} \mathrm{C}$. Specimens were dehydrated in a graded series of ethanol and embedded in Spurr's medium (Spurr 1969). Ultrathin sections of 60 to $80 \mathrm{~mm}$ thickness were stained with alkaline lead citrate (Reynolds 1963) for $30 \mathrm{~s}$ or $1 \mathrm{~min}$ and examined in a Zeiss EM 9 S-2 or a Zeiss EM 10 electron microscope.
Light microscopy. Semi-thin plastic sections of $0.5 \mu \mathrm{m}$ were stained with methylene blue - Azur II (Richardson et al. 1960; modified) and used for orientation. For visualization of glycogen, semi-thin sections were incubated in an alkaline $1 \%$ solution of silver diamine for $1.5 \mathrm{~h}$ at $60^{\circ} \mathrm{C}$ (Singh 1964). After rinsing in distilled water, sections were mounted in Entellan (Serva Chemicals, Heidelberg, Germany) and examined in a Zeiss photomicroscope II.

Morphometric procedures. Sampling and morphometric evaluation were performed according to the procedures by Weibel et al. (1969) and Weibel (1979). The primary sample consisted of 6 tissue liver blocks from each fish. Four blocks were selected at random to represent the secondary sample. These blocks were sectioned at a thickness of $0.5 \mu \mathrm{m}$ for high-resolution light microscopy and at 60 to $90 \mathrm{~nm}$ for electron microscopy. The tertiary sample consisted of micrographs recorded on sections of the secondary samples.

Three levels of magnification were employed (Table 1): from $0.5 \mu \mathrm{m}$ thick sections, 1 light micrograph per section was recorded at a final magnification of $\times 1100$, from ultrathin sections, at least 10 electron micrographs were taken per section, thus yielding a final sample of $\geq 40$ micrographs per fish at magnification levels of $\times 7200$ and $\times 18000$. Finally, the micrographs used for morphometry were sampled randomly according to the principles of Weibel (1979).

The volume density $\left(V_{v i}\right)$ was estimated by placing a test point lattice with a defined number of test points on a micrograph and by determining the fraction of these points enclosed within profiles of the structure investigated. Test points falling on extrahepatocellular structures (bile canaliculi, sinusoids, etc.) were subtracted from the total number of test points. All data presented were calculated with hepatocytes as reference space. The volume density of nuclei $\left(V_{V n h}\right)$ was determined on light micrographs using a test point lattice with 391 points spaced systematically at a distance of $d=10 \mathrm{~mm}$ on the test point lattice (equivalent to $9.091 \mu \mathrm{m}$ in the tissue). For measurement of volume

Table 1. Tiers of stereological analysis and cytological parameters investigated. PT: test points on grid; $d$ : distance between test points; LM: light micrograph; EM: electron micrograph; RER: rough endoplasmic reticulum

\begin{tabular}{|c|c|c|c|c|c|c|}
\hline \multirow[t]{2}{*}{ Stage } & \multirow[t]{2}{*}{ Magnification } & \multirow{2}{*}{$\begin{array}{l}\text { Section thick- } \\
\text { ness (nm) }\end{array}$} & \multicolumn{2}{|c|}{ Test system } & \multicolumn{2}{|c|}{ Parameters measured } \\
\hline & & & $\mathrm{PT}$ & $d(\mu \mathrm{m})$ & Volume density & Numerical density \\
\hline Tier 1 & $\begin{array}{l}1100 \times \\
(\mathrm{LM})\end{array}$ & $\begin{array}{c}500-750 \\
\text { (semithin) }\end{array}$ & $\begin{array}{c}\text { Square } \\
391\end{array}$ & $\begin{array}{c}\text { Lattice } \\
9.091\end{array}$ & $\begin{array}{l}\text { Nuclei } \\
\text { Glycogen }\end{array}$ & Nuclei \\
\hline Tier 2 & $\begin{array}{c}7200 \times \\
(E M)\end{array}$ & $\begin{array}{c}150-200 \\
\text { (ultrathin) }\end{array}$ & $\begin{array}{c}\text { Square } \\
391\end{array}$ & $\begin{array}{c}\text { Lattice } \\
1.388\end{array}$ & $\begin{array}{l}\text { Mitachondria } \\
\text { Lysosomes } \\
\text { Lipid }\end{array}$ & $\begin{array}{l}\text { Mitochondria } \\
\text { Lysosomes } \\
\text { Lipid }\end{array}$ \\
\hline Tier 3 & $\begin{array}{c}18000 \times \\
(E M)\end{array}$ & $\begin{array}{l}150-200 \\
\text { (ultrathin) }\end{array}$ & $\begin{array}{c}\text { Square } \\
391\end{array}$ & $\begin{array}{c}\text { Lattice } \\
0.555\end{array}$ & $\begin{array}{c}\text { Peroxisomes } \\
\text { RER }\end{array}$ & Peroxisomes \\
\hline
\end{tabular}


densities of hepatic mitochondria $\left(V_{V_{\text {mio }}}\right)$ lipid ( $\left.V_{\text {Vlipid }}\right)$ and lysosomes ( $V_{\text {Vlyso }}$ ) electron micrographs and a test point lattice with 391 systematically spaced points at a distance of $d=10 \mathrm{~mm}$ on the test point lattice (equivalent to $1.388 \mu \mathrm{m}$ in the tissue) were employed. Volume density of hepatocellular glycogen fields ( $\left.V_{\text {Vglyc }}\right)$ was estimated on electron micrographs with a test point lattice of 96 points spaced at a distance of $d=20 \mathrm{~mm}$ (equivalent to $2.778 \mu \mathrm{m}$ in the tissue). Volume densities of endoplasmic reticulum $\left(V_{V E R}\right)$ and peroxisomes $\left(V_{\text {Vperox }}\right)$ were determined on micrographs with a test point lattice with 108 points spaced at a distance of $d=$ $20 \mathrm{~mm}$ (equivalent to $1.111 \mu \mathrm{m}$ in the tissue)

The numerical densities $\left(N_{v_{i}}\right)$ of particulate hepatocyte structures within the test area were calculated according to the formula (Weibel et al. 1969, Weibel 1979):

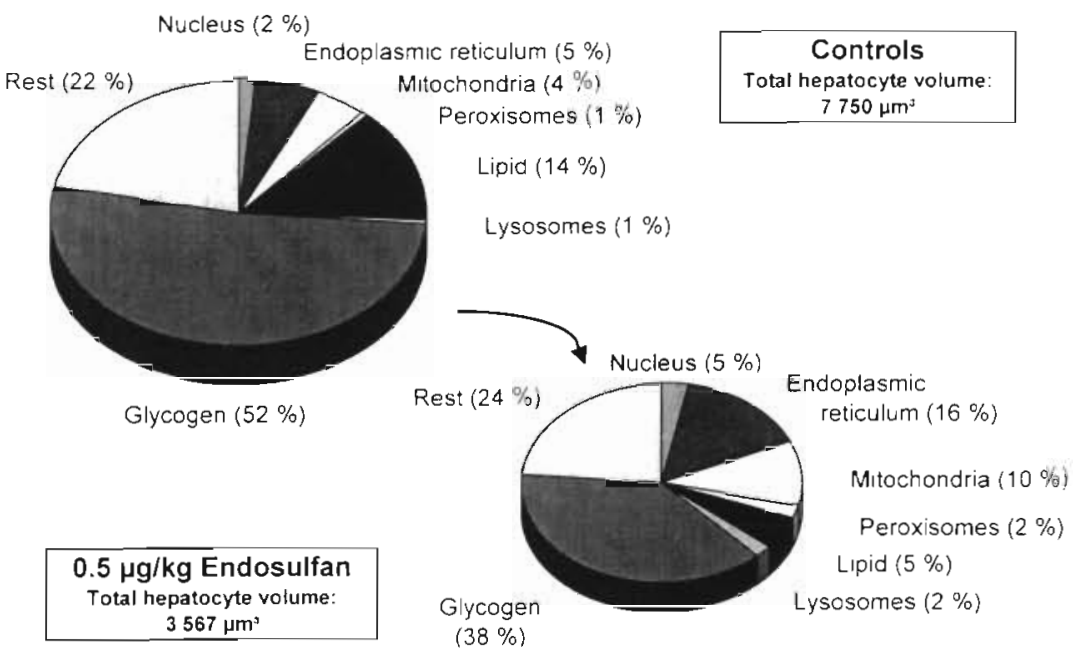

$$
N_{V_{1}}=(1 / b)\left(N_{A_{1}}\right)^{3 / 2} /\left(V_{V_{i}}\right)^{1 / 2}
$$

\section{Reaction of the liver to endosulfan}

where $N_{\mathrm{A} \text { I }}$ is the number of actually counted hepatocellular profiles divided by the test area, $V_{\mathrm{Vi}}$ is the volume density of the profile, and $b$ is a shape-dependent coefficient. This coefficient $b$ was assumed to be 1.38 for nuclei, lysosomes, lipid and peroxisomes, and 2.25 for mitochondria (Weibel et al. 1969). Numerical density of hepatocytic nuclei $\left(N_{\mathrm{Vnh}}\right)$ was determined from light micrographs of semi-thin sections. The number of hepatocytes per unit volume of hepatocytic tissue $\left(1 \mathrm{~cm}^{3}\right)$ was calculated from the numerical density $\left(N_{V n h}\right)$ of hepatocytic nuclei obtained by the aforementioned procedure. Numerical densities of mitochondria $\left(N_{V \text { mito }}\right)$, lysosomes $\left(N_{V \mid y s o}\right)$, and lipid ( $\left.N_{\text {Vlipid }}\right)$ were calculated from electron micrographs at $\times 7200$; numerical density of peroxisomes ( $N_{\text {Vperox }}$ ) was estimated from micrographs at $\times 18000$. The numbers of the structures investigated per hepatocyte were computed from $N_{\mathrm{Vi}} / N_{\mathrm{Vnh}}$.

Statistical procedures. Mean values from morphometric measurements were compared using the non-parametric Wilcoxon-Mann-Whitney U-test (Sachs 1984).

\section{RESULTS}

Carp Cyprinus carpio exposed to endosulfan did not show any alterations in behavioral patterns and feeding activity. Likewise, growth was not retarded following exposure to endosulfan, and no macroscopically overt signs of pathology could be discerned during dissection.
Liver of control carp

Morphometric alterations are summarized in Figs. 1 $\& 2$ as well as Tables $2 \& 3$ ). The hepatocytes of control carp measured approx. $20 \mu \mathrm{m}$ in diameter and were characterized by abundant glycogen and lipid deposits (Figs. $3 \& 6$ ), but a comparatively limited development of endoplasmic reticulum and Golgi fields. Organellecontaining portions of the cytoplasm were strictly separated from areas of reserve materials (intracellular compartmentation, cf. Braunbeck et al. 1989).

The nucleus (approx. $6 \mu \mathrm{m}$ in diameter) was of regular outline and contained a central electron-dense

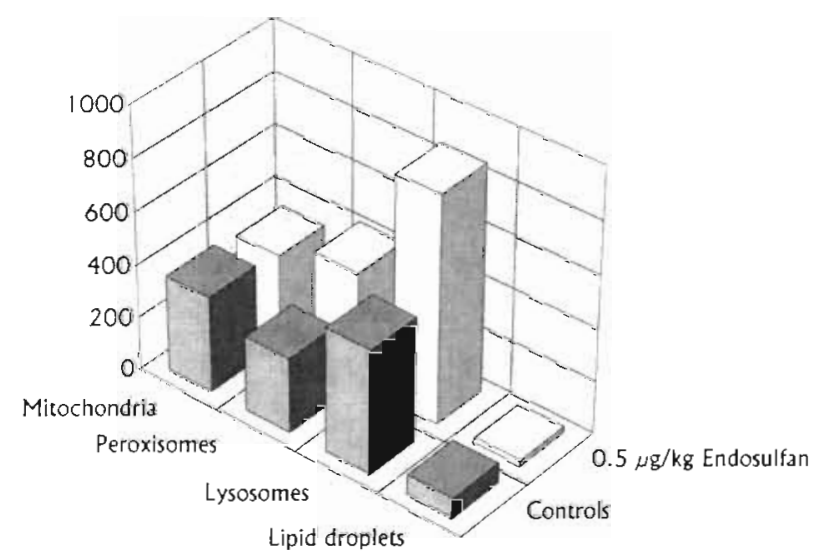

Fig. 2. Cyprinus carpio. Numerical alterations in selected cell components of carp hepatocytes caused by exposure to $0.5 \mathrm{\mu g}$ $\mathrm{kg}^{-1}$ endosulphan 
Table 2. Volume and numerical densities of liver cell components in carp exposed to $0.5 \mu \mathrm{g} \mathrm{kg}^{-1}$ endosulfan (per os). Volume and numerical densities are related to hepatocytes as reference space. Data are given as means $\pm S D$; $n=4$. Differences between controls and exposed fish were evaluated by the Wilcoxon-Mann-Whitney $U$-test: " $p<0.05$

\begin{tabular}{|c|c|c|}
\hline & Controls & $0.5 \mu \mathrm{g} \mathrm{kg}^{-1}$ endosulfan \\
\hline \multicolumn{3}{|l|}{ Nuclei } \\
\hline Volume density $\left(\mathrm{cm}^{3} \mathrm{~cm}^{-3}\right)$ & $0.014 \pm 0.003$ & $0.029 \pm 0.005^{\circ}$ \\
\hline Numerical density $\left(10^{9} \mathrm{~cm}^{-3}\right)$ & $129.02 \pm 10.25$ & $280.30 \pm 52.76^{\circ}$ \\
\hline \multicolumn{3}{|l|}{ Endoplasmic reticulum } \\
\hline Volume density $\left(\mathrm{cm}^{3} \mathrm{~cm}^{-3}\right)$ & $0.054 \pm 0.003$ & $0.155 \pm 0.036^{\circ}$ \\
\hline \multicolumn{3}{|l|}{ Mitochondria } \\
\hline Volume density $\left(\mathrm{cm}^{3} \mathrm{~cm}^{-3}\right)$ & $0.044 \pm 0.014$ & $0.101 \pm 0.042$ \\
\hline Numerical density $\left(10^{9} \mathrm{~cm}^{-3}\right)$ & $99.45 \pm 12.45$ & $95.77 \pm 17.56$ \\
\hline \multicolumn{3}{|l|}{ Peroxisomes } \\
\hline Volume density $\left(\mathrm{cm}^{3} \mathrm{~cm}^{-3}\right\}$ & $0.006 \pm 0.001$ & $0.024 \pm 0.004^{\circ}$ \\
\hline Numerical density $\left(10^{9} \mathrm{~cm}^{-3}\right)$ & $36.45 \pm 4.53$ & $118.76 \pm 9.61^{\circ}$ \\
\hline \multicolumn{3}{|l|}{ Lysosomes } \\
\hline Volume density $\left(\mathrm{cm}^{3} \mathrm{~cm}^{-3}\right)$ & $0.006 \pm 0.002$ & $0.021 \pm 0.005^{\circ}$ \\
\hline Numerical density $\left(10^{9} \mathrm{~cm}^{-3}\right)$ & $61.03 \pm 0.05$ & $242.00 \pm 65.17^{\circ}$ \\
\hline \multicolumn{3}{|l|}{ Lipid } \\
\hline Volume density $\left(\mathrm{cm}^{3} \mathrm{~cm}^{-3}\right)$ & $0.138 \pm 0.010$ & $0.051 \pm 0.005^{\circ}$ \\
\hline Numerical density $\left(10^{9} \mathrm{~cm}^{-3}\right)$ & $9.67 \pm 2.00$ & $5.88 \pm 0.90^{\circ}$ \\
\hline \multicolumn{3}{|l|}{ Glycogen fields } \\
\hline Volume density $\left(\mathrm{cm}^{3} \mathrm{~cm}^{-3}\right)$ & $0.520 \pm 0.060$ & $0.382 \pm 0.035^{\circ}$ \\
\hline
\end{tabular}

Table 3. Mean volume, size, and number of different organelles in hepatocytes of carp exposed to $0.5 \mu \mathrm{g} \mathrm{kg} \mathrm{kg}^{-1}$ endosulfan (per os). Data given as calculated from values in Table 1 as follows: hepatocytic diameter as third root of hepatocytic volume; nuclear diameter assuming spherical nuclear shape; organelle volume as organelle volume density $\times$ hepatocytic volume

\begin{tabular}{|c|c|c|}
\hline & Controls & $0.5 \mu \mathrm{g} \mathrm{kg}^{-1}$ endosulfan \\
\hline \multicolumn{3}{|l|}{ Hepatocyte (mononuclear) } \\
\hline Mean volume $\left(\mu \mathrm{m}^{3}\right)$ & 7750.64 & 3567.55 \\
\hline Mean diameter $(\mu \mathrm{m})$ & 19.79 & 15.28 \\
\hline \multicolumn{3}{|l|}{ Nuclei } \\
\hline Mean volume $\left(\mu \mathrm{m}^{3}\right)$ & 114.23 & 105.90 \\
\hline Mean diameter $(\mu \mathrm{m})$ & 6.02 & 5.87 \\
\hline Nuclear-cytoplasmic ratio & 0.015 & 0.030 \\
\hline \multicolumn{3}{|l|}{ Endoplasmic reticulum } \\
\hline Volume hepatocyte ${ }^{-1}\left(\mu^{3}\right)$ & 418.53 & 552.97 \\
\hline \multicolumn{3}{|l|}{ Mitochondria } \\
\hline Volume hepatocyte ${ }^{-1}\left(\mu^{3}\right)$ & 342.76 & 359.26 \\
\hline Mitochondria hepatocyte ${ }^{-1}$ & 362 & 342 \\
\hline \multicolumn{3}{|l|}{ Peroxisomes } \\
\hline Volume hepatocyte $\mathrm{e}^{-1}\left(\mu^{3}\right)$ & 46.50 & 85.62 \\
\hline Peroxisomes hepatocyte ${ }^{-1}$ & 283 & 424 \\
\hline \multicolumn{3}{|l|}{ Lysosomes } \\
\hline Volume hepatocyte ${ }^{-1}\left(\mu^{3}\right)$ & 48.42 & 75.12 \\
\hline Lysosomes hepatocyte ${ }^{-1}$ & 472 & 862 \\
\hline \multicolumn{3}{|l|}{ Lipid } \\
\hline Volume hepatocyte ${ }^{-1}\left(\mu^{3}\right)$ & 1069.59 & 181.95 \\
\hline Lipid droplets hepatocyte & 75 & 21 \\
\hline \multicolumn{3}{|l|}{ Glycogen fields } \\
\hline Glycogen volume hepatocyte ${ }^{-1}\left(\mu^{3}\right)$ & 4030.33 & 1362.80 \\
\hline $\begin{array}{l}\text { Volume of cell parameters not } \\
\text { measured indvidually }\left(\mu^{3}\right)^{a}\end{array}$ & 1680.28 & 843.93 \\
\hline \multicolumn{3}{|c|}{$\begin{array}{l}\text { a Parameters mainly comprise Golgi fields, bile canaliculi and cytoplas- } \\
\text { mic matrix and are calculated as difference between hepatocytic vol- } \\
\text { ume and total of parameters measured individually }\end{array}$} \\
\hline
\end{tabular}

nucleolus (average diameter $1.4 \mu \mathrm{m}$ ), several patches of heterochromatin in random distribution and a marginal rim of heterochromatin. It was enveloped by stacks of rough endoplasmic reticulum (RER) comprising 1 to 3 parallel, non-fenestrated cisternae up to $8 \mu \mathrm{m}$ long (Fig. 6). Single or paired RER lamellae also sheathed mitochondria, which appeared as spherical or elongated profiles with a diameter of up to $0.7 \mu \mathrm{m}$ and a length of up to $3.5 \mu \mathrm{m}$; occasionally, twisted and branched mitochondrial profiles were evident.

Peroxisomes mainly appeared as spherical particles with a diameter ranging from 0.8 to $2.2 \mu \mathrm{m}$, and were closely associated to single non-fenestrated cisternae of RER and mitochondria (see Fig. 12). They always lacked an amorphous or crystalline core, and their matrix was of homogeneous, slightly granular appearance.

The hepatocytes of uncontaminated carp were virtually free of smooth endoplasmic reticulum (SER); only occasionally could small fragments of SER be found in intimate association to Golgi fields and bile canaliculi. Golgi fields were of limited extension and consisted of 1 to 3 straight, hardly fenestrated lamellae. As a rule, 1 or 2 dictyosomes could be distinguished per cell section. Lysosomes were small and scarce; they were restricted to the peribiliary area.

Both glycogen stores and lipid deposits were abundant in control carp hepatocytes (Figs. 1, $3 \& 6$ ). The lipid inclusions ranged from 0.3 to $4.5 \mu \mathrm{m}$ in diameter and were randomly distributed over the peripheral cytoplasmic areas.

In quantitative terms, the majority of the hepatocellular volume was occupied by glycogen fields $(52 \%)$ and lipid (14\%); among the organelles measured, the endoplasmic reticulum accounts for $5 \%$, followed by mitochondria (4\%), whereas peroxisomes and lysosomes comprise only $0.6 \%$ (Fig. 1, Table 2)

\section{Liver of endosulfan-exposed carp}

Whereas nuclear diameter and volume were unaffected by exposure to endosulfan exposure (Table 3), the mean diameter 

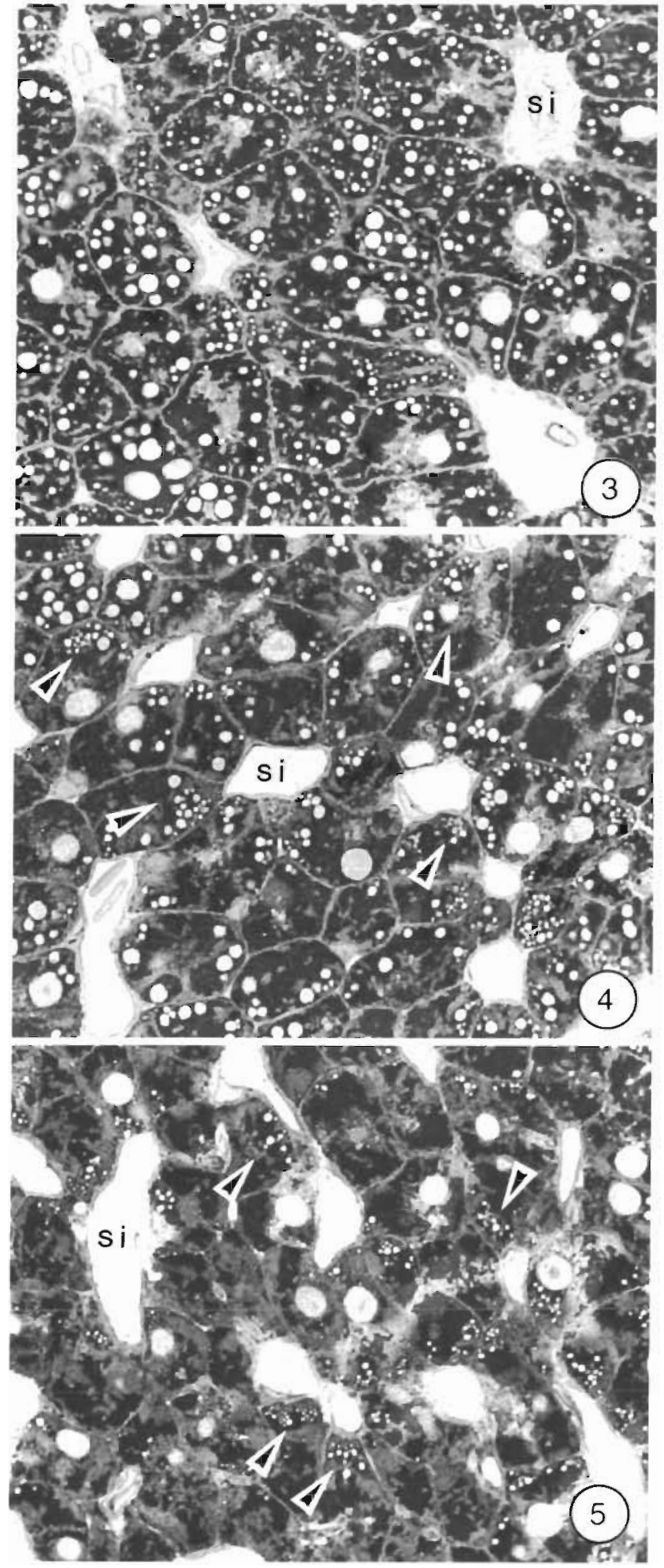

of the hepatocytes displayed a conspicuous decline by about $25 \%$ to approx. $15 \mu \mathrm{m}$ (Figs. 4, 5 \& 7), the decrease being mainly due to a reduction. in glycogen
Figs. 3 to 5. Cyprinus carpio. Light micrographs of the anterior liver portion of control tish (Fig. 3) and fish exposed to $0.5 \mu \mathrm{g}$ $\mathrm{kg}^{-1}$ endosulfan (Figs. $4 \& 5$ ). $0.5 \mu \mathrm{m}$ resin sections stained for glycogen with the silver diamine impregnation technique. si: sinusoids; $\times 630$. Fig. 3 . In control fish, hepatocytes display a clear-cut separation into intensely stained peripheral glycogen areas and a perinuclear zone of organelle-containing cytoplasm. Lipid inclusions are randomly distributed within the glycogen areas. Figs. $4 \& 5$. In fish exposed to $0.5 \mu \mathrm{g} \mathrm{kg}^{-1}$ endosulfan, there is a conspicuous decline in cell size and the number of lipid inclusions. In the liver portion shown in Fig. 4, lipid depletion is less prominent than in the area depicted in Fig. 5. Note the accumulation of the remaining lipid accumulations at the sinusoidal pole of the hepatocytes (arrowheads)

and lipid deposits (Fig. 1, Tables 2 \& 3). As was already evident on low-power electron micrographs (Fig. 7), the amount of RER had drastically increased and lipid deposits were concentrated at the sinusoidal pole of the hepatocytes.

The nuclear outline appears less regular than in controls (Figs. 7, 8,9\& 11), and the number of binucleate hepatocytes was elevated (Fig. 9). The diameter of the central nucleolus had increased by up to $150 \%$ to a maximum of $3.3 \mu \mathrm{m}$ (Figs. $7,8 \& 9$ ).

In all fish investigated, the most conspicuous cytological alteration was the increase in the amount of RER and SER: according to quantitative determination, the proliferation of the endoplasmic reticulum was in the range of $200 \%$, resulting in hepatocytes containing up to $15 \%$ endoplasmic reticulum (ER) (Table 2). Both number and extension of RER stacks had drastically increased, thus suggesting a higher capacity of protein synthesis (Figs. 7, 8 \& 9). The piles were located around the nucleus and in peripheral regions of the cells, where they were made up of up to 18 parallel, only occasionally fenestrated RER lamellae; the longitudinal extension of the stacks ranged from 4 to $6.5 \mu \mathrm{m}$. The SER showed a remarkable proliferation in consequence of endosulfan expo-

Figs. $6 \& 7$. Cyprinus carpio. Fig. 6. Low-power electron micrograph of a control hepatocyte. The cell is dominated by vast accumulations of glycogen in the cell periphery. Lipid inclusions are scattered over the peripheral storage areas. Rough endoplasmic reticulum (RER) around the spherical nucleus is scarce. ca: bile canaliculus, gly: glycogen, nl: nucleolus. $\times 4700$. Fig. 7. Hepatocytes of carp exposed to $0.5 \mu \mathrm{g} \mathrm{kg}^{-1}$ endosulfan. Cell size is reduced. The nuclear outline $(*)$ appears less regular, and the RER forms extensive stacks. The size of Golgi fields (arrowheads) has increased. The amount of reserve materials is less than in controls, and lipid droplets accumulate at the vascular cell pole. gly: glycogen ma: macrophage, nl: nucleolus. $\times 2900$ 


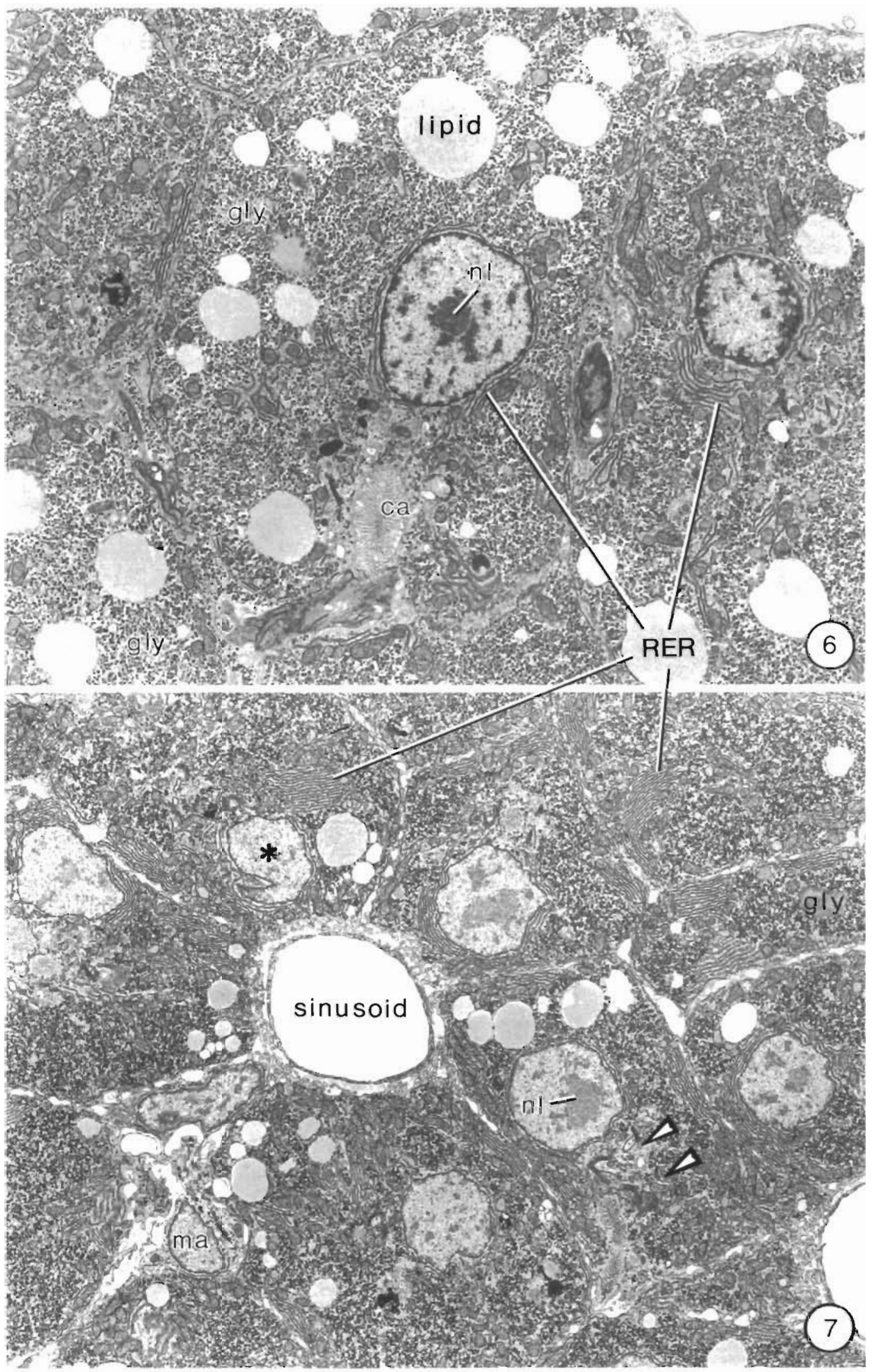




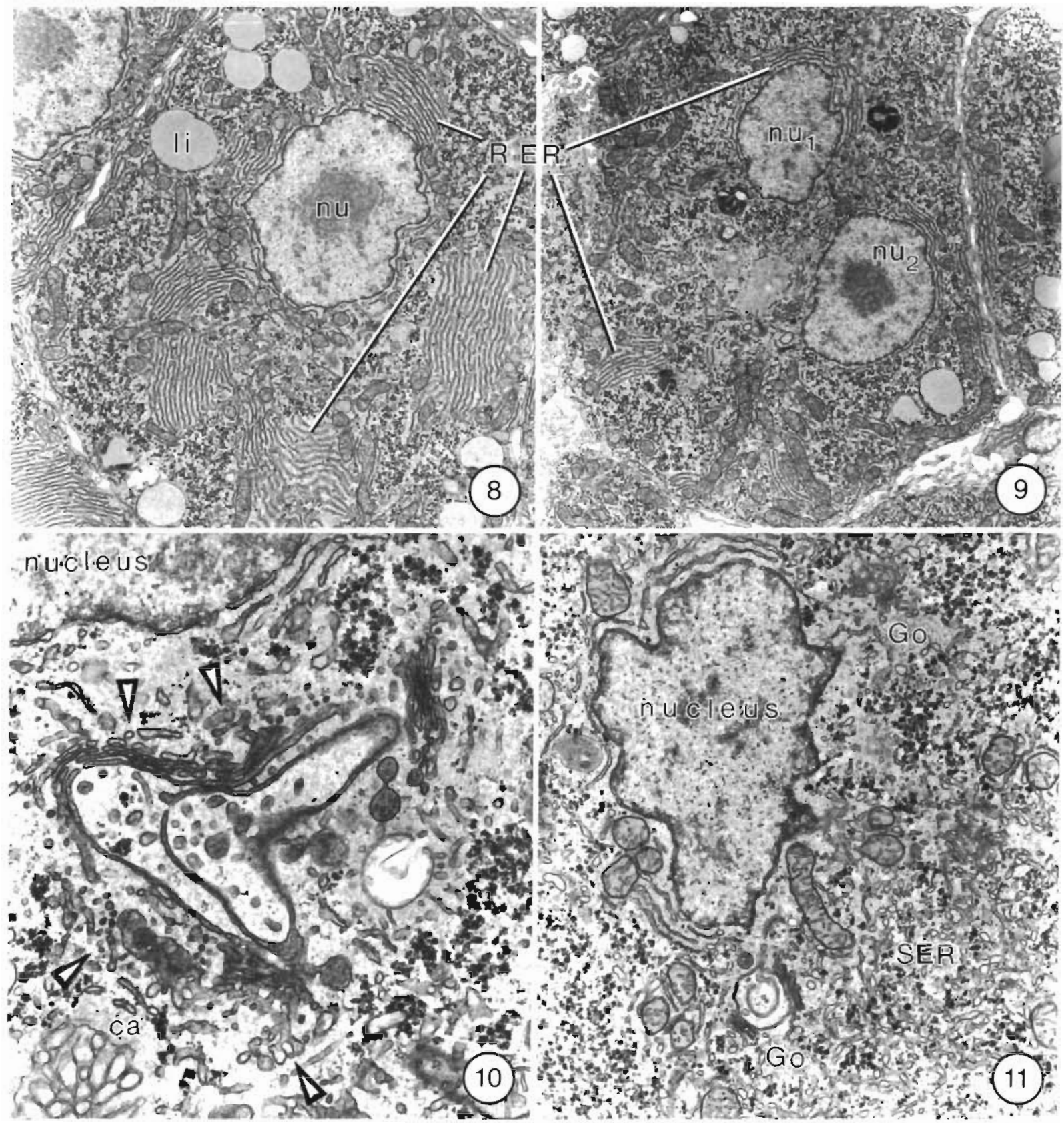

Figs. 8 to 11. Cyprinus carpio Fig. 8. Number and extensıon of hepatocytıc RER stacks have drastically increased following exposure to endosulfan. RER pules around the nucleus (nu) and in the peripheral cytoplasm are composed of up to 18 parallel, occasionally tenestrated RER lamellae 11 . lipid $\times 4800$ Flg. 9. Endosulfan exposure induces a numerical augmentation of binucleate cells $\left(\mathrm{nu}_{1}, \mathrm{nu}_{2}\right)$ in carp liver $\times 3600$ Fig. 10 Hepatocytıc Golgı flelds in exposed fish display an increase in number and size. The dictyosomes frequently appear as circular profles, the trans-most cisternae (arrowheads) are highly fenestrated. ca: bile canalıculus $\times 22200$ Fig. 11. Carp after exposure to endosultan; hepatocytes display a remarkable proliferation of the smooth endoplasmic retıculum (SER). Go Golgı fields. $\times 10600$

sure (Figs. $1 \& 11$ ) extensive fields of cytoplasm were replenished with an elaborate network of short tubular and vesicular anastomosing profiles of SER randomly distributed between glycogen rosettes. The sheath of endoplasmic retıculum around mitochondria and peroxisomes was often highly fenestrated or virtually absent (Fig 11).

In parallel to the alterations in the endoplasmic reticulum, Golgı fields displayed an augmentation in number and size (Fig. 10). The dictyosomes frequently 
Figs. 12 to 14 . Cyprinus carpio. Fig. 12. In control carp liver, single peroxisomes and mitochondria are frequently in intimate association with each other and are enveloped by cisternae of the RER $\times 15100$. Fig. 13. Carp after exposure to endosulfan; carp hepatocytes show a marked proliferation of peroxisomes, which tend to form large aggregations. Size and shape of peroxisomes display an increased heterogeneity. $\times 13500$. Fig. 14. Irregular mitochondrial profiles such as ring-like cross-sections indicate an increased variability in shape and size of mitochondria after exposure to endosulfan. $\times 39400$

appeared as circular profiles (Figs. 10 \& 11), the transmost cisternae were highly fenestrated and budded off an increased number of Golgi vesicles (Fig. 10). A numerical and volumetric increase, both in relative (Fig. 1, Table 2) and absolute terms (Fig. 2, Table 3), could also be observed in lysosomes, which often contained lipid droplets in various stages of degradation.

In fish exposed to endosulfan, hepatocytes exhibited the formation of peroxisome aggregations (Fig. 13): Whereas in controls peroxisomes appeared as isolated, circular profiles of regular outline in close affiliation with RER and mitochondria (Fig. 13), peroxisome accumulations in fish exposed to endosulfan were composed of irregularly shaped particles mostly without conspicuous association with other organelles. Peroxisomal size ranged from 0.1 to $1.2 \mu \mathrm{m}$, i.e. peroxisomes in these aggregates were smaller than in controls. In total, however, as calculated from the peroxisomal volume and number per hepatocyte (Fig. 2, Table 3), the average volume of a single peroxisome was $0.16 \mu \mathrm{m}^{3}$ in control hepatocytes and $0.20 \mu^{3}$ in endosulfanexposed specimens. Volume and numerical densities as well as the number of peroxisomes per hepatocyte were significantly higher than in control specimens (Fig. 1, Table 2). Moreover, morphological heterogeneity of peroxisomes was significantly increased. There were no alterations in the appearance of the peroxisomal matrix.

Whereas the absolute volume and number of mitochondria per hepatocyte were unaltered after endosulfan exposure (Table 3), both volume density and relative volume had increased, mainly due to a reduction in hepatocytic volume (Table 2). Variability in shape and size of mitochondria had increased; most frequently, circular profiles could be encountered (Fig. 14).

In contrast to most of the organelles, the volumes of both glycogen fields and lipid per hepatocyte were diminished by 66 and $83 \%$, respectively, if related to a single hepatocyte (Figs. $4 \& 5$, Table 3 ). Whereas in most cells the size range of lipid inclusions was unaffected by endosulfan, there was a striking concentration of lipid droplets along the perisinusoidal face of

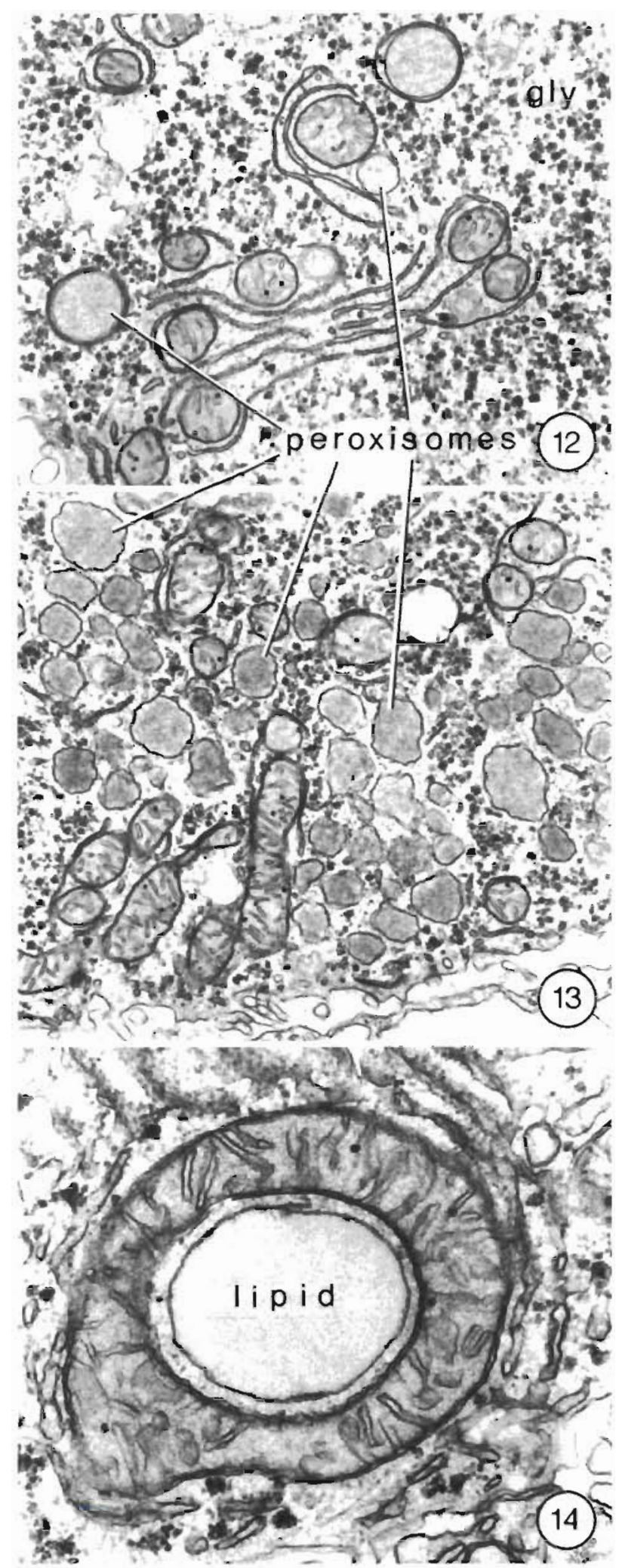

the hepatocytes (Figs, 4, 5, $6 \& 8$ ). On rare occasions, large glycogen accumulations of extreme packaging density could be found in cell portions free of other cell 

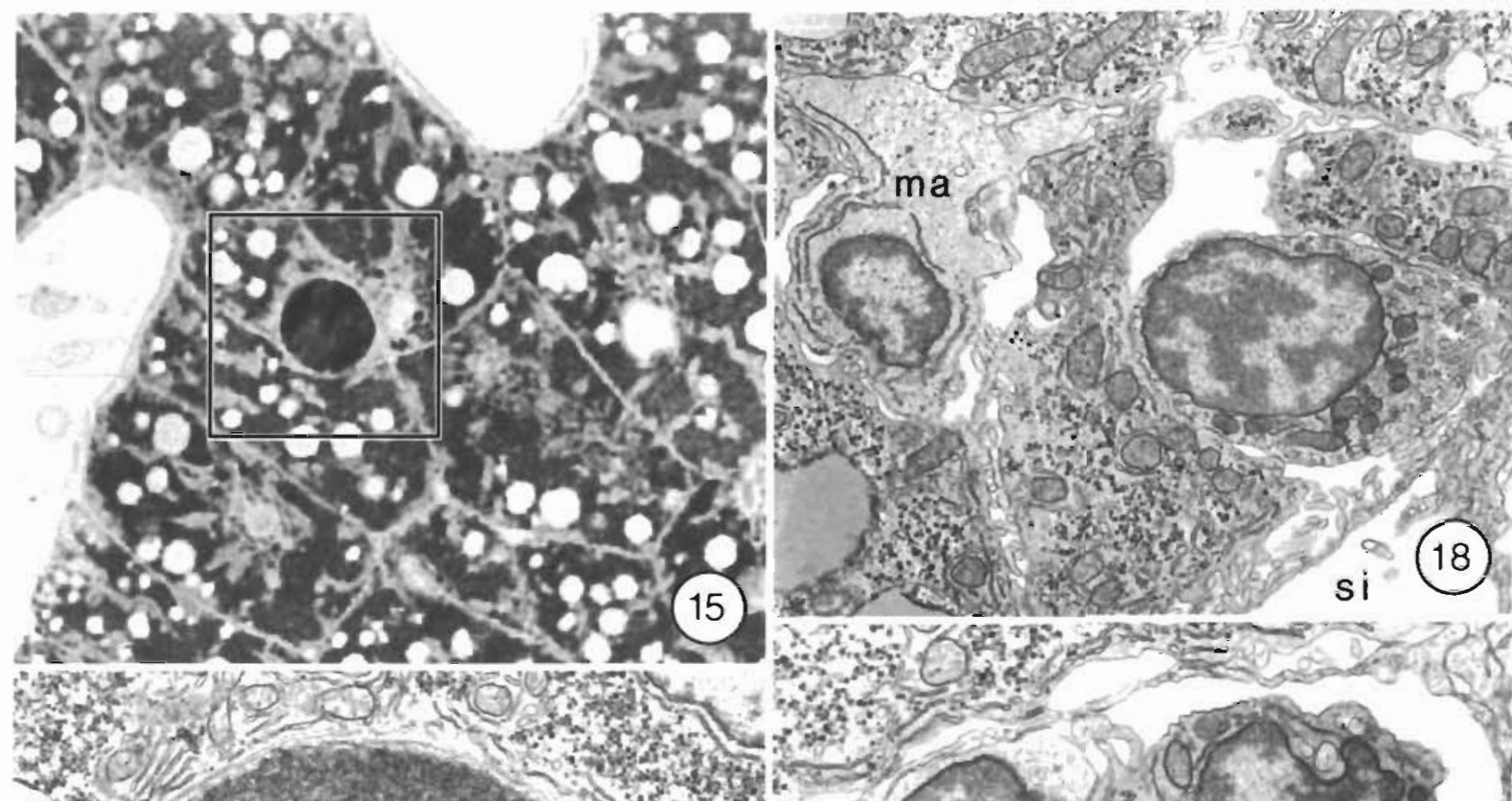

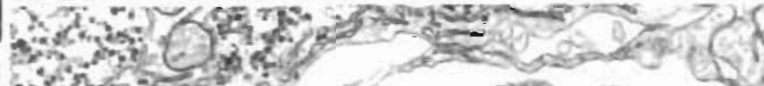
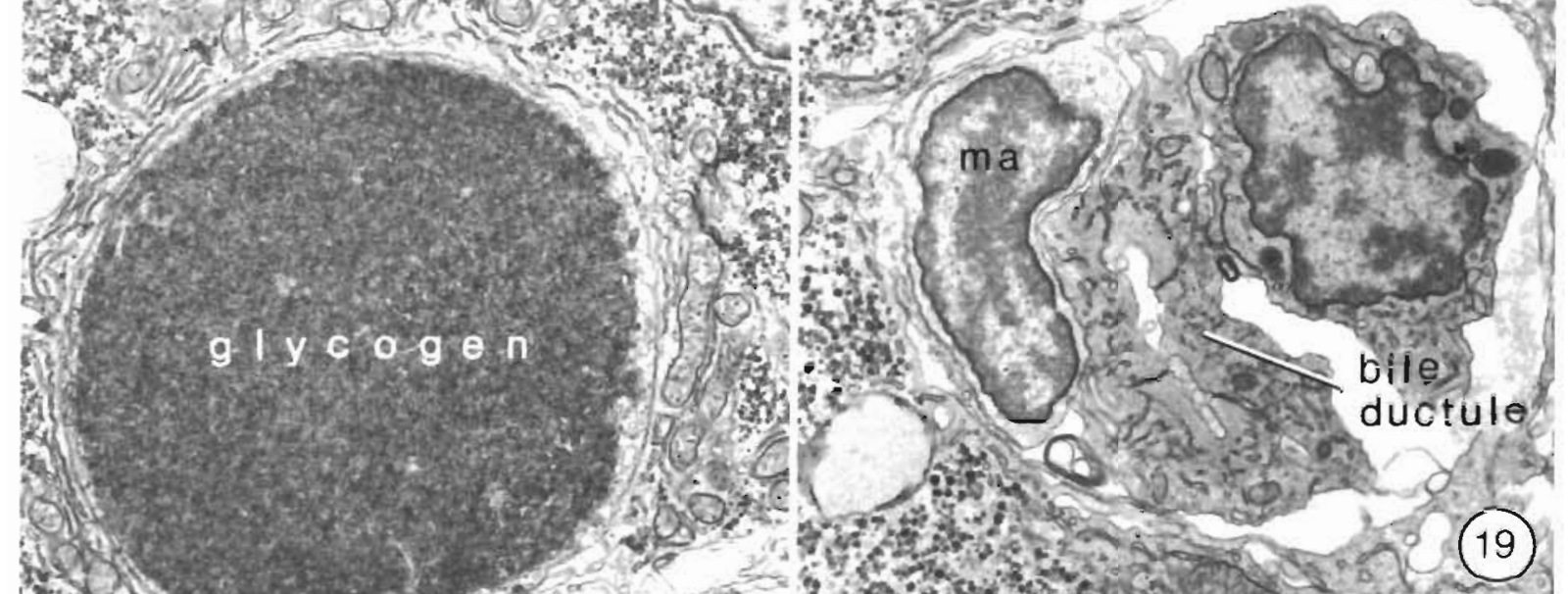

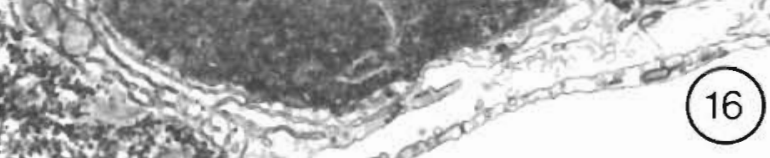

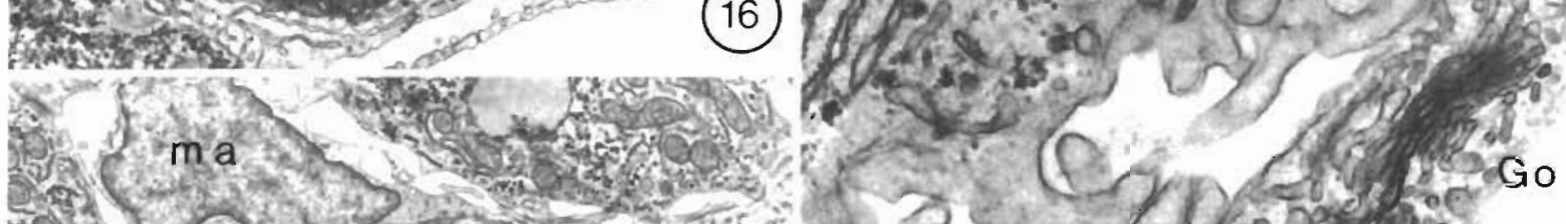

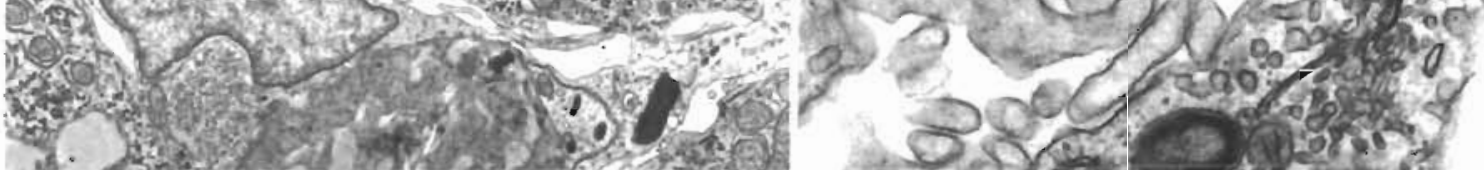

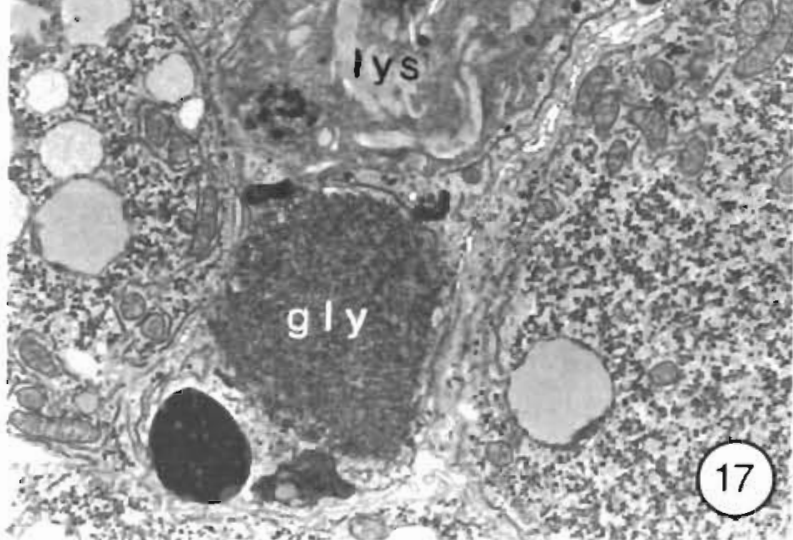

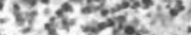

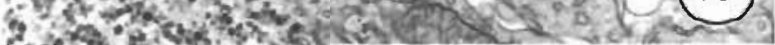
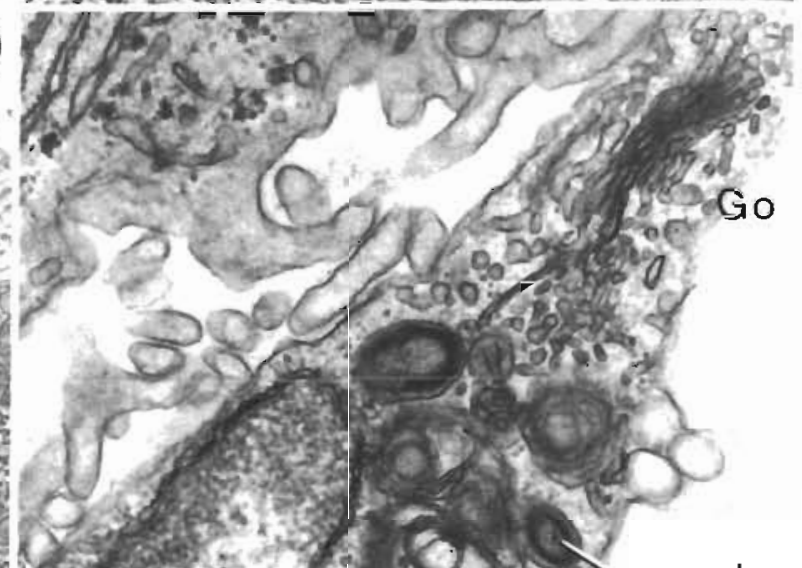

10

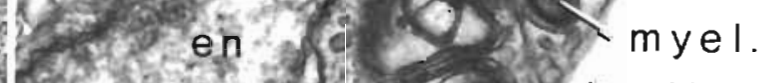

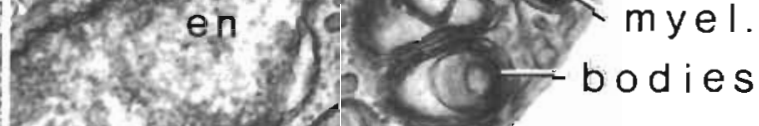

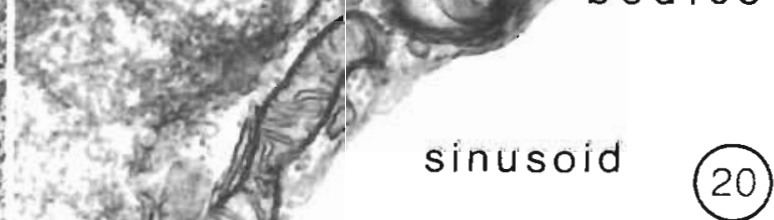


Figs. 15 to 20. Cyprinus carpio. Figs. 15 to 17. In hepatocytes of carp exposed to endosulfan, huge glycogen accumulations of very high packaging density can be found (Figs. $15 \& 16$ ). Similar glycogen accumulations (gly) are detectable within the remnants of hepatocytes taken up by immigrating macrophages (ma, Fig. 17). lys: lysosome. Fig. 15: $\times 1200$; Fig. 16: $\times 7600 ;$ Fig. 17: $\times 5700$. Figs. 18 \& 19. Carp following exposure to endosulfan; there is an invasion of macrophages (ma) into the liver parenchyma via the perisinusoidal space of Disse (Fig. 18) or along the biliary system (Fig. 19): si: sinusoid. Fig. 18: $\times 6900 ;$ Fig. $19: \times 10900$. Fig. 20. In the endothelial cells (en), endosulfan induces hypertrophy of the Golgi complex (Go) and aggregations of myelinated bodies. $\times 31500$

components (Figs. $15 \& 16$ ); the origin of these cells could not be established, but they were assumed to be derived from hepatocytes.

With regard to non-parenchymal components of the liver, endosulfan exposure resulted in an immigration of macrophages via the perisinusoidal space of Disse (Fig. 18) and along the biliary preductules and ductules (Fig. 19). Interestingly, in some of the macrophages, glycogen condensations similar to those described above could be observed (Fig. 19; compare to Fig. 16). Most likely, they originated from phagocytosis of hepatocytic glycogen accumulations.

Further cytological alterations could be demonstrated in the endothelial lining of the sinusoids. In parallel to the changes within hepatocytes, there was a hypertrophy of Golgi fields in addition to the occurrence of clusters of myelinated bodies (Fig. 20).

\section{Reaction of the intestine to endosulfan}

Intestine of control carp

Since no cytological alterations in consequence of endosulfan exposure could be observed in intestinal region II (for terminology of intestinal regions, see Stroband et al. 1979), only region I will be considered in detail.

The enterocytes of intestinal region I can be identified as high columnar cells measuring ca $60 \mu \mathrm{m}$ with a comparatively low, homogeneous microvillus border of ca $1 \mu \mathrm{m}$ (Fig. 21). The intercellular space between enterocytes was limited to a width of $\leq 100 \mathrm{~nm}$ and displayed numerous chylomicrons. The most apical cytoplasmic layer reached a height of $0.7 \mu \mathrm{m}$, was almost free of organelles and housed a few tiny vesicles and the terminal web above a zone particularly rich in mitochondria, ER profiles and lipid droplets (Fig. 21). Lysosomes and myelinated bodies were scarce in control carp.

The central cell portion was occupied by vesicular and cisternal profiles of RER, free ribosomes, peroxisomes and Golgi fields (Fig. 22). The dictyosomes consisted of both flat lamellae and cisternae, which appeared slightly distended and, in tangential sections, perforated. Vesicles of varying size had budded off the Golgi fields and displayed numerous chylomicrons

The elongated nucleus, measuring $10 \mu \mathrm{m}$ along its longitudinal axis, was located in the basal third of the enterocytes and displayed only little heterochromatin and a conspicuous nucleolus. The most basal portion of the cell again contained numerous mitochondria in close association to some ER lamellae and an elaborate system of lamellar structures derived from indentations by the basal and lateral cell membranes (Fig. 23).

Intestine of endosulfan-exposed carp

The reaction of the enterocytes of intestinal region I to food-borne endosulfan was characterized by distension of the intercellular space and drastic stimulation of lysosomes within the cells.

The most conspicuous cytological alteration was the proliferation of the lysosomal compartment. Lysosomes characterized by low electron density and highly condensed material in their center as well as myelinated structures in the periphery had increased both in number and size (Figs. $24 \& 25$ ). Occasionally, long, slender crystalline inclusions could be identified in the lysosomal matrix (Fig. 25). Lysosomes accumulated predominantly in the supranuclear portion of the enterocytes.

The intercellular space appeared enlarged, reaching a width of up to $1.5 \mu \mathrm{m}$ (on rare occasions $3.5 \mu \mathrm{m}$ ), and was virtually free of chylomicrons. Following exposure to endosulfan, the number of chylomicrons within the enterocytes was subject to a drastically increased intraindividual variability, as compared to control specimens. Lipid inclusions could not be discerned in the enterocytes of endosulfan-exposed fish.

As in the liver, there was an immigration of macrophages in the intercellular space after feeding endosulfan-contaminated food (Fig. 26). Within these phagocytes, myelinated bodies accumulated to form clusters and composite structures. The origin of the myelinated bodies, however, could not be identified. Moreover, an unusually high rate of mucous cell precursors indicated a stimulation of mucous cell turnover after endosulfan exposure. 

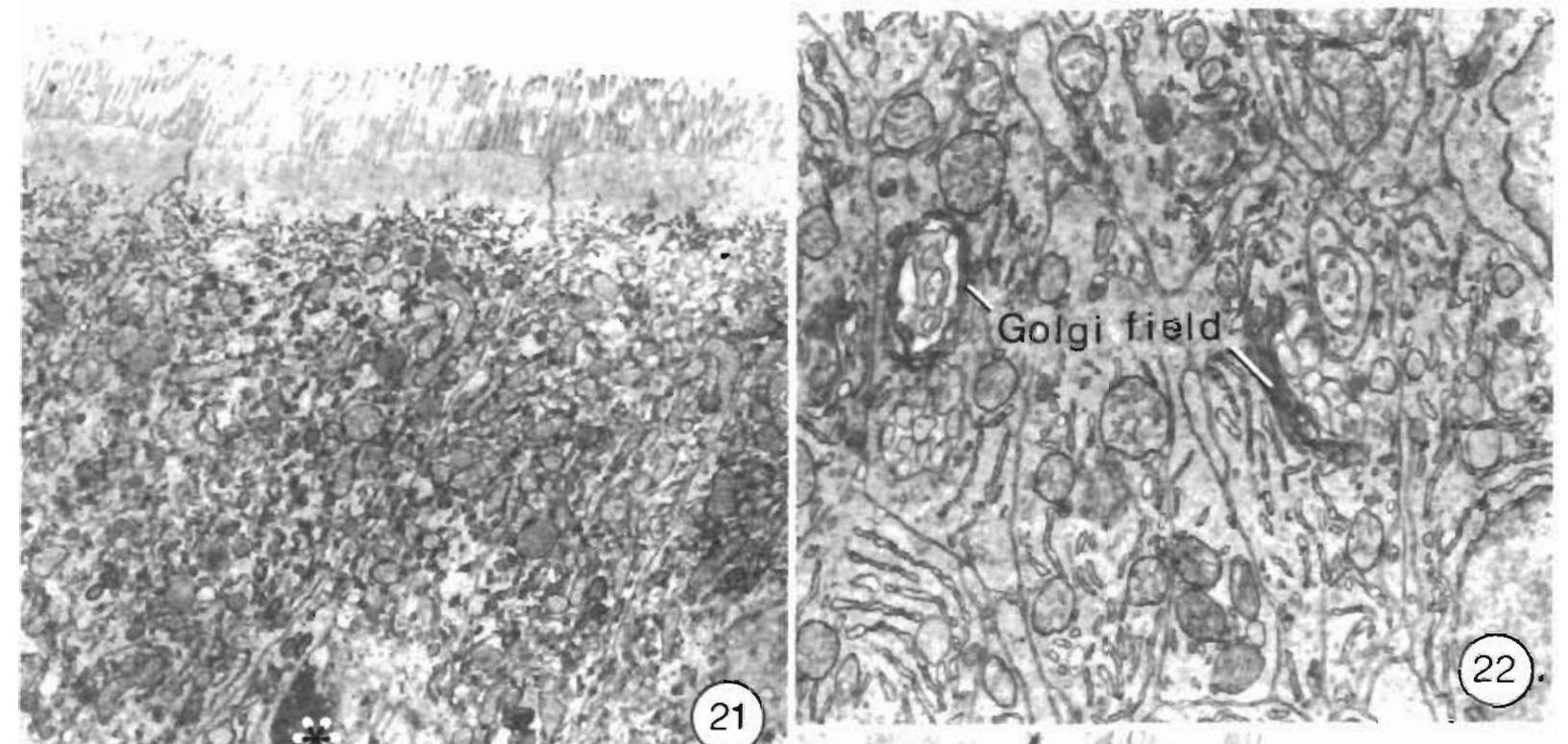

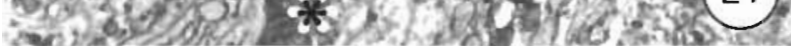

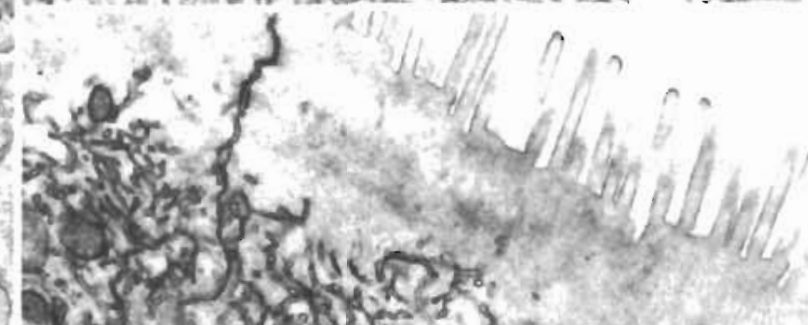

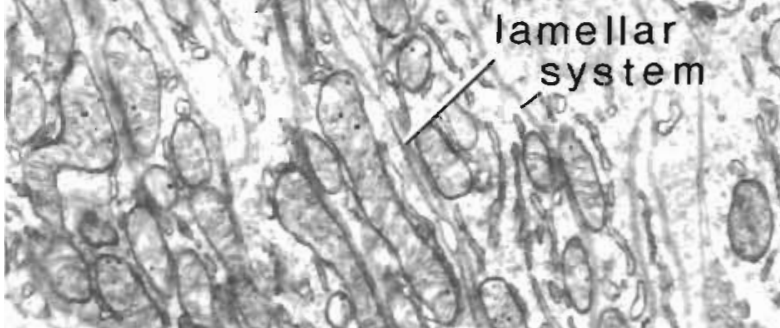

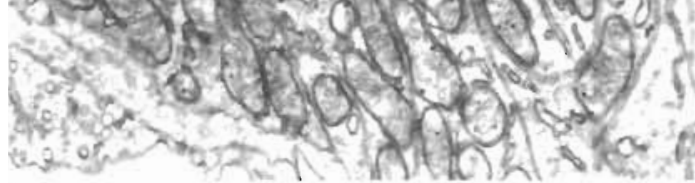

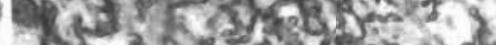

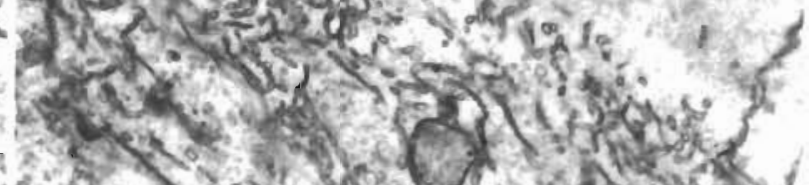

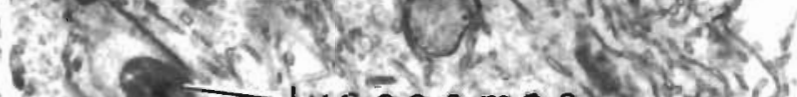

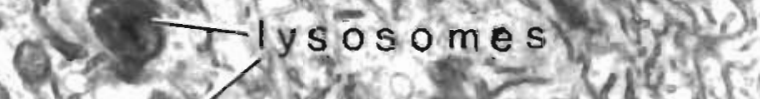
If $=2$ a

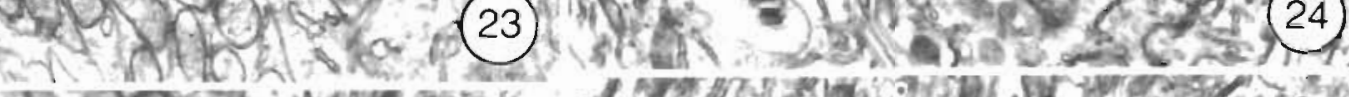

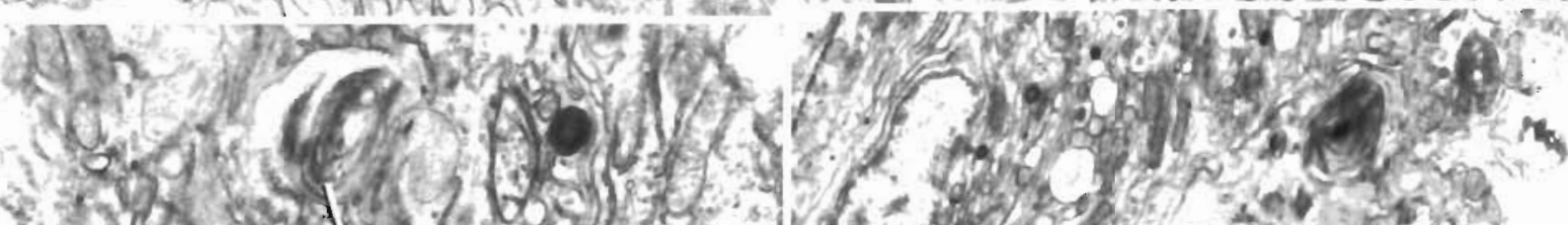

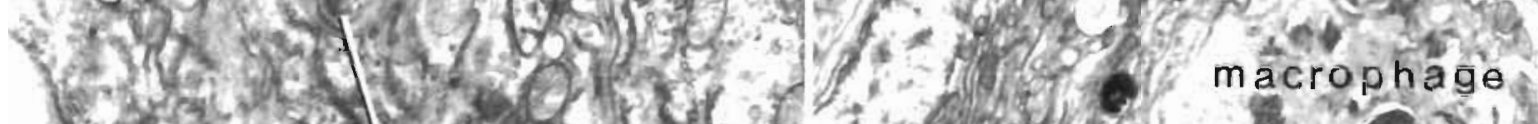

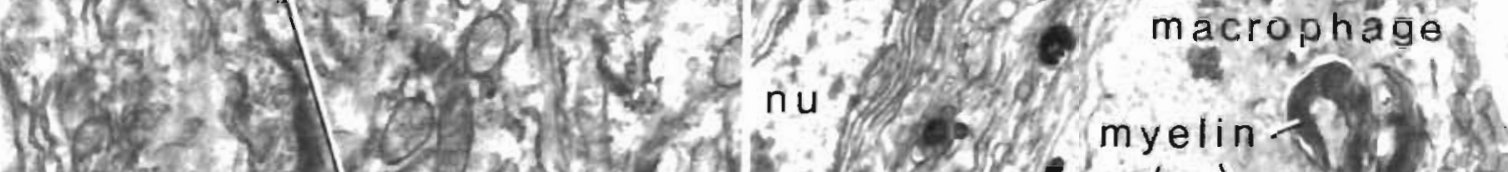

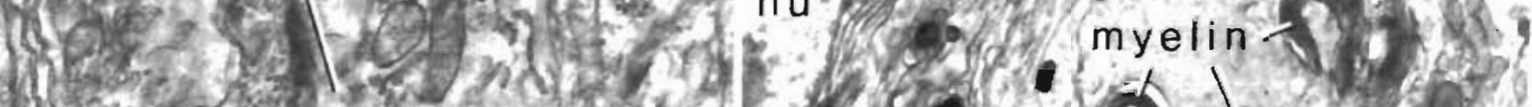

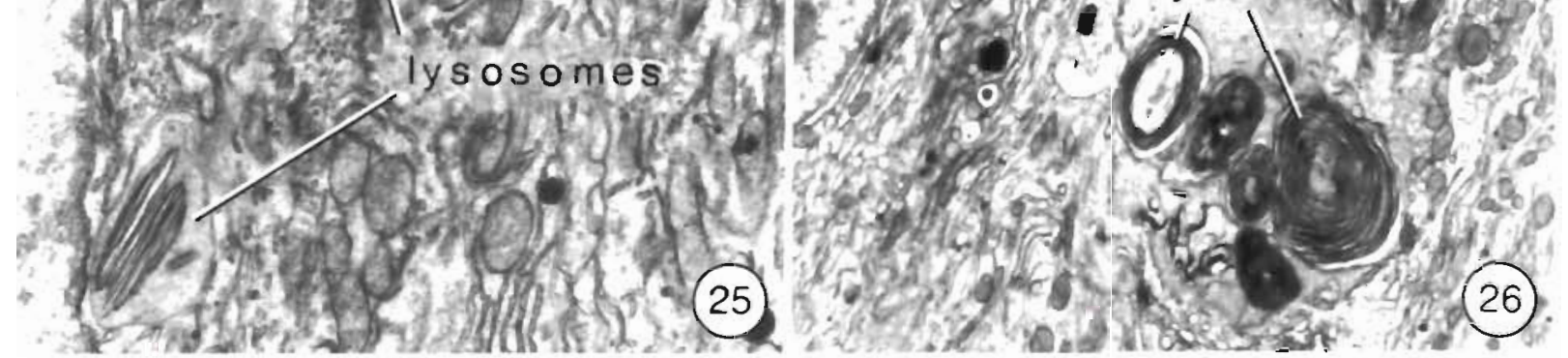


Figs. 21 to 26. Cyprinus carpio. Figs. 21 to 23. In intestinal region I, the apices of enterocytes are characterized by a zone particularly rich in mitochondria, endoplasmic reticulum (ER) profiles and lipid droplets (Fig. 21). The intercellular space between enterocytes displays chylomicrons (*). The central cell portion is occupied by profiles of RER and Golgi fields (Fig. 22). The basal cell part contains numerous mitochondria in close association to some ER lamellae and an elaborate system of lamellar structures derived from indentations by the basal and lateral cell membranes (Fig. 23). nu: nucleus. Fig. 21: $\times 7100 ;$ Figs. $22 \& 23: \times 14300$. Figs. 24 \& 25. After contamination with endosulfan, enterocytes display numerous lysosomes in their apical (Fig. 24) and central (Fig. 25) portions. $\times 14300$. Fig. 26. Macrophages containing large myelinated structures penetrate the intestinal epithelium. nu: nucleus of enterocyte. $\times 7100$

\section{DISCUSSION}

The present communication served a triple purpose: (1) to demonstrate the uptake of endosulfan via contaminated food by fish, (2) to investigate the reaction of hepatic and intestinal ultrastructure to trace concentrations of the pesticide, and (3) to evaluate the possible involvement of endosulfan in a fish kill in the river Rhine following the chemical spill at Basel in November 1986.

The induction of manifold alterations in enterocytes and hepatocytes clearly documents the uptake of endosulfan from contaminated food and, thus, corroborates the conclusion drawn by Herzberg (1986) from residue measurements in various organs of tilapia Oreochromis aureus and carp. In several mammalian species, the oral intake of endosulfan has been established (Den Tonkelaar \& Van Esch 1974, Gupta \& Gupta 1979, Ansari et al. 1984). Compared to experiments with mammals, however (oral dose in the range of 1 to $10 \mathrm{mg} \mathrm{kg}^{-1}$, e.g. Tyagi et al. 1984), the dosage applied in the present experiment, i.e. $0.5 \mu \mathrm{g} \mathrm{kg} \mathrm{kg}^{-1}$ food, equivalent to $15 \mathrm{ng} \mathrm{kg}^{-1}$ fish $\mathrm{d}^{-1}$, is extremely low and emphasizes the extraordinary susceptibility of fish not only to acute, but also to sublethal levels of endosulfan.

The first organ to come into contact with pesticidecontaminated food particles is the intestinal tract. The histological and cytological changes observed in the intestinal epithelium, i.e. proliferation of lysosomes, distension of the intercellular space, invasion of macrophages and stimulation of mucous cell turnover, have to be classified as unspecific reactions of the intestinal mucosa to stress. Distension of the intercellular space has, for example, been described in eel Anguilla anguilla stomach by Peters (1982) as a consequence of social stress. An increase in acid phosphatase, a key enzyme for lysosomes, in Channa striatus has been documented not only after exposure to endosulfan, but also to other pesticides (Arora \& Kulshrestha 1985). Although the diagnostic importance of the histological and cytological modifications is thus limited, they appear of relevance for the interpretation of the metabolic processes stimulated by endosulfan.
The reduction in the amount of lipid inclusions in the enterocytes, which were regarded as sites of shortterm storage, in conjunction with the diminution of chylomicrons in both Golgi vesicles and intercellular space indicate a decline in intestinal resorption of lipid catabolism products and, thus, might account for the lower lipid stores in the liver after endosulfan exposition. Damage to the intestinal mucosa of Channa punctatus has also been postulated by Sastry \& Siddiqui $(1982,1983)$ as the reason for an impairment of glucose resorption after acute and chronic exposure to endosulfan. In analogy to lipid uptake, reduced intestinal carbohydrate resorption could equally serve as one explanation for the decline in hepatic lipid stores. Further evidence for the interference of endosulfan with intestinal resorption and transport processes is provided by the inhibition of brush border-bound alkaline phosphatase reported by Arora \& Kulshrestha (1985). Thus, the present study provides cytological evidence for an impairment of intestinal transport processes as a first mode of toxic action by endosulfan.

In contrast to these truly pathological symptoms, the proliferation of intestinal mucous cells most likely represents an adaptive mechanism activated to protect the epithelium from pesticide attack.

Whereas the observations in the liver of control carp are in line with literature data (Byczkowska-Smyk 1970, Gas 1973, Kramar et al. 1974, Rutschke \& Brozio 1974, Rojik et al. 1983, Benedeczky et al. 1984, 1986, Storch et al. 1984), numerous cytological changes of an adaptive or compensatory nature could be listed in the liver of endosulfan-exposed carp. In conjunction with an enlarged nucleolus, a highly significant increase in the amount of RER together with the hypertrophy of the Golgi fields indicate a stimulation of hepatic protein synthesis, which, in turn, most likely provides the basis for the proliferation of the SER.

SER augmentation has been generally accepted as the morphological equivalent to the induction of biotransformation processes (Klaunig et al. 1979, Schoor \& Couch 1979, Hawkes 1980, Gingerich 1982, Hinton et al. 1987, Braunbeck et al. 1989, 1990a,c, Braunbeck \& Völkl 1991). In the rat, endosulfan was actually shown to stimulate an increase in hepatic microsomal protein 
(Narayan et al. 1985) and to function as a weak inducer of biotransformation enzymes (Den Tonkelaar \& Van Esch 1974, Tyagi et al. 1984, 1985, Siddiqui et al. 1987) and to provoke an increase of SER membranes (Agarwal et al. 1978, Tyagi et al. 1984). Similarly, endosulfan has been shown to induce hepatic phase I biotransformation enzymes including cytochrome P450 (Jensen et al. 1991). The fact that most of the endosulfan metabolites are excreted via the bile indicates that the liver is the major site of endosulfan metabolism and excretion in fish (Schoettger 1970, Rao et al. 1980, Rao \& Murty 1982, Herzberg 1986). However, as pointed out by Klaunig et al. (1979), Schoor \& Couch (1979), Braunbeck et al. (1989), as well as Lester et al. (1992, 1993), there is evidence that in both fish and mammals (cf. Antoine et al. 1984) the RER is also involved in hepatic biotransformation processes. From this point of view, the drastic increase in the amount of hepatic RER in endosulfan-exposed carp could also be interpreted as a direct, adaptive response to intoxication. In both rainbow trout Oncorhynchus mykiss exposed to waterborne endosulfan (Arnold \& Braunbeck 1993, 1994, Arnold et al. 1996a) and rainbow trout simultaneously contaminated with endosulfan and the phosphorodithionate pesticide disulfoton (Arnold et al. 1995. $1996 a, b)$ there was a similar increase in the amount of endoplasmic reticulum cisternae.

The stimulation of hepatocytic metabolism is further substantiated by an increase in the number of binucleated cells as well as by a $200 \%$ proliferation and cluster formation of peroxisomes. Whereas the stimulation of karyokinesis may be interpreted as a means to increase the amount of DNA relative to cytoplasm, and thus, to meet elevated metabolic demands, the functional significance of peroxisome aggregation remains unclear.

Lysosomal proliferation, a less regular nuclear shape, enhanced morphological variability of mitochondria, reduced carbohydrate and lipid deposits as well as immigration of macrophages into the hepatic parenchyma are likely to represent unspecific signs of stress (Braunbeck et al. 1989, 1990a,b). The diminution in hepatic glycogen has also been noted in other fish species (Murty \& Devi 1982, Sastry \& Siddiqui 1983, Verma et al. 1983) and could be either due to increased glycolytic activity to meet the energy demands imposed by enhanced metabolic activity, to hormonemediated stress phenomena (Hanke et al. 1983, Gluth \& Hanke 1985), or to reduced intestinal absorption of carbohydrates as discussed above. Since the amount of food ingested was apparently not reduced, the latter explanation might also hold true for the decline in hepatic lipid stores (cf. Murty \& Devi 1982). In rats, a direct stimulation of hepatic lipid peroxidation has been reported (Agarwal et al. 1978). The functional correlate to the polarization of lipid inclusions towards the vascular pole of the hepatocytes, however, remains obscure.

Interestingly, endosulfan also produced cytological effects in the endothelial epithelia of carp liver. Normally, in the liver of fish, chemically induced cytotoxic lesions are almost exclusively restricted to parenchymal cells (Hinton et al. 1988). However, in eel exposed to the chemical spill in 1986, the endothelial cells also displayed an augmentation of lysosomal elements and changes in the activity of Golgi fields (Braunbeck et al. 1990a).

The numerous histological and cytological alterations observed in the liver and intestine in contrast to the complete lack of externally discernible effects of endosulfan exposure emphasize the importance of structural and functional investigations in the diagnosis of possible adverse effects of xenobiotics. Stereological techniques serve to complement, quantitatively substantiate and increase the sensitivity of primarily qualitative morphological studies. The present morphological and morphometric study provides several indications to the site and possible modes of toxic action of the xenobiotic substance (cf. Hinton et al. 1987 ). For the assessment of the diagnostic value of the observations, pathological lesions may be classified into regenerative responses mediating defense mechanisms and irreversible, degenerative reactions (Altmann 1980, Sindermann 1984, Braunbeck et al. 1990a, Braunbeck 1998). Except for some unspecific, stressrelated changes such as depletion of reserve materials, most of the alterations described, especially those in the liver, are of an adaptive or compensatory nature. This raises the question as to the ecotoxicological significance of such stimulating effects of chronic endosulfan exposure, which have also been reported for $\mathrm{Na}^{+}-\mathrm{K}^{+}$-dependent ATPase in fish liver and kidney (Sharma 1988), as well as for other processes in various fish organs such as the pancreas (Amminikutty \& Rege 1977).

With regard to the fish kill in the river Rhine following the chemical spill at Basel in November 1986, not only truly pathological symptoms, but also adaptive phenomena appear of importance. In a model calculation based on a bioconcentration factor of 1000 (cf. Schimmel et al. 1977, Verschueren 1983), contamination of the food particles with $0.5 \mu \mathrm{g} \mathrm{kg} \mathrm{kg}^{-1}$ might be related to water-borne endosulfan concentrations of $0.5 \mathrm{ng} \mathrm{l}^{-1}$. Thus, the 'cytological lowest observed effect concentration' ('cytological' LOEC) is about 3 orders of magnitude below the maximum acceptable toxicant concentration (MATC) listed as 0.2 to $0.4 \mu \mathrm{g} \mathrm{l}^{-1}$ for the fathead minnow by Mc Kim (1977). Concentrations of $0.5 \mu \mathrm{g} \mathrm{l}^{-1}$ could well have been reached after the accident in 1986. Since adsorption of endosulfan to 
particulate material and accumulation in the river sediments appears possible (Greve \& Wit 1971, Deutsche Kommission zur Reinhaltung des Rheins 1986), exposure time may have been sufficient for the induction of the cytological alterations described both in previous (Braunbeck et al. 1990a, Arnold et al. 1995, 1996a) and in the present communication.

The bulk of the organic chemicals spilled into the river Rhine consisted of $>500 \mathrm{t}$ of organophosphate esters such as disulfoton, thiometon, propetamphos, etc., but also parathion, the toxicity of which is known to be considerably amplified due to bioactivation by hepatic and, to a lower extent, extrahepatic NADPHdependent mixed-function oxidases (Arnold \& Braunbeck 1993, 1994, Arnold et al. 1995, 1996a,b), which, in turn, can be induced by other stimulants (Murphy 1986). Thus, endosulfan may have contributed to the overall toxicity of the chemicals released during the chemical spill in 1986, less as a toxicant in itself than as a stimulant for the toxicity of other components. The activating potency of endosulfan has most likely been intensified by other stimulating pesticides released simultaneously, such as dinitro-o-cresol (Braunbeck \& Völkl 1991, 1993).

Further experiments have been initiated (1) to reveal possible alterations of low concentrations of endosulfan in fish kidney, (2) to study interspecies variation in the reaction of fish liver to endosulfan, and (3) to investigate possible additive or synergistic interactions of endosulfan with other pesticides released during the chemical spill at Basel in 1986 (cf. Arnold \& Braunbeck 1993, Arnold et al. 1995).

Acknowledgements. This study was carried out at the Aquaculture Laboratory of The Jacob Blaustein Institute for Desert Research, Ben Gurion University, at Sede Boqer, Israel. Thanks are due to the Ben Gurion University for awarding a grant to T.B. Histological analysis was supported by a grant (Sandoz-Fonds) by the Landesanstalt für Umweltschutz of the state of Baden-Württemberg (Germany) by contract no. 12/180.17.24. The authors are particularly grateful to Dr P. Burkhardt-Holm for her kind support in the analysis of the intestinal tract and Mrs G. Adam, C. Brell and F. Müller for excellent technical assistance.

\section{LITERATURE CITED}

Agarwal DK, Seth PK, Gupta PK (1978) Effect of endosulfan on drug-metabolizing enzymes and lipid peroxidation in rat. J Environ Sci Health 13C:49-62

Altmann HW (1980) Drug-induced liver reactions: a morphological approach. Curr Top Pathol 69:69-142

Amminikutty CK, Rege MS (1977) Effects of acute and chronic exposure to pesticides, Thiodan E.C. \& Agallol ' 3 ' on the liver of the widow tetra Gymnocorymbus ternetzi (Boulenger). Indian J Exp Biol 15:197-200

Ansari RA, Siddiqui MKJ, Gupta PK (1984) Toxicity of endosulfan: distribution of $\alpha$-isomer and $\beta$-isomer of racemic endosulfan following oral administration in rats. Toxicol Lett 21:29-34

Antoine B, Magdalou J, Siest G (1984) Kinetic properties of UDP-glucuronyltransferase(s) in different membranes of rat liver cells. Xenobiotica 14:575-579

Arnold H, Braunbeck T (1993) Subletale Toxizität von Schadstoffgemischen: die Wirkung von Endosulfan und Disulfoton auf die Leber der Regenbogenforelle (Oncorhynchus mykiss). Verh Dtsch Zool Ges 86:189

Arnold $H$, Braunbeck T (1994) Qualitative und quantitative Effekte in Leberzellen der Regenbogenforelle (Oncorhynchus mykiss) infolge einer subletalen Endosulfanexposition: bedingt das eine das andere? Verh Dtsch Zool Ges 87:70

Arnold H, Pluta HJ, Braunbeck T (1995) Simultaneous exposure of fish to endosulfan and disulfoton in vivo: ultrastructural, stereological and biochemical reactions in hepatocytes of male in rainbow trout (Oncorhynchus mykiss) liver. Aquat Toxicol 33:17-43

Arnold H, Pluta HJ, Braunbeck T (1996a) Sublethal effects of prolonged exposure to disulfoton in rainbow trout (Oncorhynchus mykiss): cytological alterations in the liver by a potent acetylcholine esterase inhibitor. Ecotoxicol Environ Saf 34:43-55

Arnold H, Pluta HJ, Braunbeck T (1996b) Cytological alterations in the liver of rainbow trout Oncorhynchus mykiss after prolonged exposure to low concentrations of waterborne endosulfan. Dis Aquat Org 25:39-52

Arora N, Kulshrestha SK (1985) Effects of chronic exposure to sublethal doses of two pesticides on alkaline and acid phosphatase activities in the intestine of a freshwater teleost, Channa striatus Bl (Channidae). Acta Hydrochim Hydrobiol 13:619-624

Baier C, Hurle K, Kirchhoff J (1985) Datensammlung zur Abschätzung des Gefahrenpotentials von Pflanzenschutzmittel-Wirkstoffen für Gewässer DVWK Schriften 74 , Parey, Hamburg

Basak PK, Konar SK (1976) Toxicity of six insecticides to fish. Geobius (Lyon) 3:209-210

Basak PK, Konar SK (1977) A new method for the determination of safe concentrations of insecticides to protect fishes. Indian J Environ Health 19:283-293

Benedeczky I, Biro P, Schaff Z (1984) The effect of 2,4-D-containing herbicide (Dikonirt) on the ultrastructure of carp (Cyprinus carpio) liver cells. Acta Biol Hung 30:107-125

Benedeczky I, Nemcsok J, Halasy K (1986) Electron microscopic analysis of the cytopathological effect of pesticides in the liver, kidney and gill tissues of carp. Acta Biol Szeged 32:69-91

Bjerregaard P, Korsgaard B, Christiansen LB, Pedersen KL, Christensen LJ, Pedersen SN, Horn P (1998) Monitoring and risk assessment for endocrine disruptors in the aquatic environment: a biomarker approach. Arch Toxicol 20(Suppl):97-107

Braunbeck T (1994) Detection of environmentally relevant pesticide concentrations using cytological parameters: pesticide specificity in the reaction of rainbow trout liver? In: Müller R, Lloyd R (eds) Sublethal and chronic effects of pollutants on freshwater fish. Blackwell, Oxford, p 15-29

Braunbeck T (1998) Cytological alterations in fish hepatocytes following in vivo and in vitro sublethal exposure to xenobiotics - structural biomarkers of environmental contamination. In: Braunbeck T, Hinton DE, Streit B (eds) Fish ecotoxicology. Birkhäuser, Basel, p 61-140

Braunbeck T, Völkl A (1991) Induction of biotransformation in the liver of eel (Anguilla anguilla L.) by sublethal exposure to dinitro-o-cresol (DNOC): an ultrastructural and biochemical study. Ecotoxicol Environ Saf 21:109-127 
Braunbeck T, Völkl A (1993) Toxicant-induced cytological alterations in fish liver as biomarkers of environmental pollution? A case study on hepatocellular effects of dinitro-o-cresol in golden ide (Leuciscus idus melanotus). In: Braunbeck T, Hanke W, Segner H (eds) Fìsh-ecotoxicology and ecophysiology. VCH, Weinheim, p 55-80

Braunbeck T, Storch V, Nagel R (1989) Sex-specific reaction of liver ultrastructure in zebra fish (Brachydanio rerio) after prolonged sublethal exposure to 4-nitrophenol. Aquat Toxicol 14:185-202

Braunbeck T, Burkhardt-Holm P, Storch V (1990a) Liver pathology in eels (Anguilla anguilla L.) from the Rhine river exposed to the chemical spill at Basle in November 1986. Limnologie Aktuell 1:371-392

Braunbeck T, Bresch $H$, Storch V (1990b) Species-specific reaction of liver ultrastructure in zebra fish (Brachydanio rerio) and trout (Salmo gairdneri) after prolonged exposure to 4-chloroaniline. Arch Environ Contam Toxicol 19: $405-418$

Braunbeck T, Storch V, Nagel R (1990c) Hepatocellular steatosis in zebrafish (Brachydanio rerio) induced by longterm exposure to $\gamma$-hexachlorocyclohexane. Ecotoxicol Environ Saf 19:355-374

Braunbeck T, Teh SJ, Lester SM, Hinton DE (1992a) Ultrastructural alterations in hepatocytes of medaka (Oryzias latipes) during the cytotoxic phase of diethylnitrosamine. Toxicol Pathol 20:179-196

Braunbeck T, Burkhardt-Holm P, Görge G, Nagel R, Negele RD, Storch V (1992b) Regenbogenforelle und Zebrabärbling, zwei Modelle für verlängerte Toxizitätstests relative Empfindlichkeit, Art- und Organspezifität in der cytopathologischen Reaktion von Leber und Darm auf Atrazin. Schriftenr Ver Wasser Boden Lufthyg 89:109-145

Burkhardt-Holm P, Braunbeck T, Storch V (1990) Auswirkung der beim Sandoz-Unfall im November 1986 in den Rhein gelangten Chemikalien auf die Ultrastruktur des Darms von Aalen. Limnologie Aktuell 1:393-404

Byczkowska-Smyk W (1970) The ultrastructure of hepatic cells of the carp (Cyprinus carpio) and the gudgeon (Gobio gobio L.). Acta Biol Cracov Ser Zool 13:105-110

Chakravorty S, Lal B, Singh TP (1992) Effect of endosulfan (thiodan) on vitellogenesis and its modulation by different hormones in the vitellogenic catfish Clarias batrachus. Toxicology 75:191-198

Den Tonkel.aar EM, Van Esch GJ (1974) No effect levels of organochlorine pesticides based on induction of microsomal liver enzymes in short-term toxicity experiments. Toxicology 2:371-380

Deutsche Kommission zur Reinhaltung des Rheins (1986) Deutscher Bericht zum Sandoz-Unfall mit Meßprogramm. Arbeitsausschuß Meßmethoden der Deutschen Kommission zur Reinhaltung des Rheins

Ferrando MD, Andreu-Moliner E, Almar MM, Cebrian C, Nunez A (1987) Acute toxicity of organochlorinated pesticides to the European eel (Anguilla anguilla). The dependency on exposure time and temperature. Bull Environ Contam Toxicol 39:365-369

Ferrando MD, Sancho E, Andreu-Moliner E (1991) Comparative acute toxicities of selected pesticldes to Anguilla anguilla. J Environ Sci Health 26:491-498

Frank R, Braun HE, Van Hove Holdrinet M, Sirons GJ, Ripley $B D$ (1982) Agriculture and water quality in the Canadian Great Lakes Basin: pesticide use in 11 agricultural watersheds and presence in stream water, 1975-1977. J Environ Qual 11:497-505

Gas N (1973) Cytophysiologie du foie de carpe (Cyprinus carpio L.). II. Modalités d'altération des ultrastructures au cours d'un jeúne expérimental prolongé. J Physiol Pàris 66:282-303

Gimeno L, Ferrando MD. Sanchez S, Andreu E (1994) Endosulfan effects on liver and blood of the eel, Anguilla anguilla. Comp Biochem Physiol 108C:343-348

Gingerich WH (1982) Hepatic toxicology in fish. In: Weber LJ (ed) Aquatic toxicology. Raven Press, New York, p 55-105

Gluth G, Hanke W (1985) A comparison of physiological changes in carp, Cyprinus carpio, induced by several pollutants at sublethal concentrations. I. The dependency on exposure time. Ecotoxicol Environ Saf 9:179-188

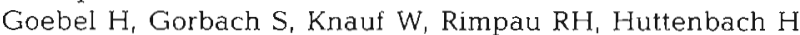
(1982) Properties, effects, residues, and analytics of the insecticide endosulfan. Residue Rev 83:1-165

Greve PA, Wit SL (1971) Endosulfan in the Rhine river J Water Pollut Contr Fed 43:1338-2348

Gupta PK, Gupta RC (1979) Pharmacology, toxicology and degradation of endosulfan: a review. Toxicology 13:115-130

Hacking MA, Budd J, Hodson K (1978) The ultrastructure of the liver of the rainbow trout: normal structure and modifications after chronic administration of a polychlorinated biphenyl Aroclor 1254. Can J Zool 56:477-491

Hanke W, Gluth G, Bubel H, Müller R (1983) Physiological changes in carp induced by pollution. Ecotoxicol Environ Saf 7:229-241

Hawkes JW (1980) The effects of xenobiotics on fish tissues: morphological studies. Fed Proc 39:3230-3236

Herzberg AM (1986) Accumulation and toxicity of endosulfan in the common carp (Cyprinus carpio) and Saint Peter's fish (Oreochromis aureus). Bamidgeh 38:99-107

Herzel F (1972) Organochlorine insecticides in surface waters in Germany - 1970 and 1971. Pestic Monit J 6:179-187

Hinton DE, Klaunig JE, Lipsky MM (1978) PCB-induced alterations in teleost liver: a model for environmental disease in fish. Mar Fish Rev 40:47-50

Hinton DE, Hampton JA, Lantz RC (1985) Morphometric analysis of liver in rainbow trout quantitatively defining an organ of xenobiotic metabolism. Mar Environ Res 17: $238-239$

Hinton DE, Lantz RC, Hampton JA, Mc Cuskey PR, Mc Cuskey RS (1987) Normal versus abnormal structure: considerations in morphological responses of teleosts to pollutants. Environ Health Perspect 71:139-146

Hinton DE, Couch JA, Teh SJ, Courtney LA (1988) Cytological changes during progression of neoplasia in selected fish species. Aquat Toxicol 11:77-112

Holcombe GW, Phipps GL, Fiandt JT (1983) Toxicity of selected priority pollutants to various aquatic organisms. Ecotoxicol Environ Saf 7:400-409

Inbaraj RM, Haider S (1988) Effect of malathion and endosulfan on brain acetylcholinesterase and ovarian steroidogenesis of Channa punctatus (Bloch). Ecotoxicol Environ Saf 16:123-128

Janardan SK, Olson CS, Schaeffer DJ (1984) Quantitative comparisons of acute toxicity of organic chemicals to rat and fish. Ecotoxicol Environ Saf 8:531-539

Jensen EG, Skaare JU, Egaas E, Goksøyr A (1991) Response of xenobiotic metabolizing enzymes in rainbow trout (Oncorhynchus mykiss) to endosulfan, detected by enzyme activities and immunochemical methods. Aquat Toxicol $21: 81-92$

Johnson WW, Finley MT (1980) Handbook of acute toxicity of chemicals to fish and aquatic invertebrates. US Dept Inter Fish WildI Serv, Res Publ 137:1-98

Joshi AG, Amminikutty J, Rege MC (1981) Chronic toxicity of some pesticides for estimating MATC for two freshwater fishes. J Environ Biol 2:43-57 
Karnovsky MJ (1971) Use of ferrocyanide-reduced osmium tetroxide in electron microscopy. J Cell Biol 51(Abstr):284

Klaunig JE, Lipsky MM, Trump BF, Hinton DE (1979) Biochemical and ultrastructural changes in teleost liver following subacute exposure to PCB. I Environ Pathol Toxicol 2:953-963

Korn S, Earnest R (1974) Acute toxicity of twenty insecticides to striped bass, Morone saxatilis. Calif Deep Fish Game Fish Bull 60:128-131

Kramar R, Goldenberg H, Böck P, Klobucar N (1974) Peroxisomes in the liver of the carp (Cyprinus carpio L.). Electron microscopic, cytochemical and biochemical studies. Histochemistry 40:137-154

Lester SM, Braunbeck TA, Teh SJ, Stegeman JJ, Miller MR, Hinton DE (1992) Immunocytochemical localization of cytochrome P 450 IA1 in liver of rainbow trout (Oncorhynchus mykiss). Mar Environ Res 34:117-122

Lester SM, Braunbeck T, Teh SJ, Stegeman JJ, Miller MR, Hinton DE (1993) Hepatic cellular distribution of cytochrome CYP $1 \mathrm{~A}$ in rainbow trout (Oncorhynchus mykiss): an immunohisto- and cytochemical study. Cancer Res 53: $3700-3706$

Lipsky MM, Klaunig JE, Hinton DE (1978) Comparison of acute response to polychlorinated biphenyl in liver of rat and channel catfish: a bjochemical and morphological study. J Toxicol Environ Health 4:107-121

Matthiessen P, Logan JW (1984) Low concentration effects of endosulfan insecticide on reproductive behavior in the tropical cichlid fish Sarotherodon mossambicus. Bull Environ Contam Toxicol 33:575-583

Mayer FL, Ellersieck MR (1986) Manual of acute toxicity: interpretation and data base for 410 chemicals and 66 species of freshwater animals. US Dept Inter Fish Wildl Serv, Res Publ 160

Mc Cain BB, Hodgins HO, Gronlund WD, Hawkes JW, Brown DW, Myers MS, Vandermeulen JH (1978) Bioavailability of crude oil from experimentally oiled sediments to English sole (Parophrys vetulus), and pathological consequences. J Fish Res Board Can 35:657-664

Mc Kim JM (1977) Evaluation of tests with early life stages of fish for predicting long-term toxicity. J Fish Res Board Can 34:1148-1154

Murphy SD (1986) Toxic effects of pesticides. In: Klaassen $\mathrm{CD}$, Amdur MO, Doull J (eds) Casarett's and Doull's toxicology. The basic science of poisons. Macmillan, New York, p 519-581

Murty AS, Devi AP (1982) The effect of endosulfan and its isomers on tissue protein, glycogen, and lipids in the fish Channa punctatus. Pestic Biochem Physiol 17:280-286

Narayan S, Bajpai A, Chauhan SS, Misra UK (1985) Lipid peroxidation in lung and liver of rats given DDT and endosulfan intratracheally. Bull Environ Contam Toxicol 34: 63-67

Pandey AC (1988) Impact of endosulfan (thiodan) EC 35 on behavior and dynamics of oocyte development in the teleostean fish, Colisa (Trichogaster) fasciatus. Ecotoxicol Environ Saf 15:221-225

Paul D, Raut SK (1987) Comparative studies on the toxicity of endosulfan in some freshwater fishes under different $\mathrm{pH}$ and hardness of water. Curr Sci (Bangalore) 56:315 - 316

Peters G (1982) The effect of stress on the stomach of the European eel, Anguilla anguilla L. J Fish Biol 21:497-512

Petit F, Le Goff P, Cravedi JP, Valotaire Y, Pakdel F (1995) Two complementary bioassays for screening the estrogenic potency of xenobiotics: recombinant yeast for trout estrogen receptor and trout hepatocyte cultures. $\mathrm{J} \mathrm{Mol}$ Endocrinol 19:321-335
Rao DMR, Murty AS (1980) Toxicity, biotransformation and elimination of endosulfan in Anabas testudineus. Ind $J$ Exp Biol 18:646-666

Rao DMR, Murty AS (1982) Toxicity and metabolism of endosulfan in three freshwater catfishes. Environ Pollut 27A: $223-231$

Rao DMR, Devi AP, Murty AS (1980) Relative toxicity of endosulfan and its isomers and formulated products to the freshwater fish Labeo rohita. J Toxicol Environ Health 6 $825-834$

Reynolds ES (1963) The use of lead citrate at high pH as an electron-opaque stain in electron microscopy. J Cell Biol $17: 208-212$

Richardson KC, Jarett L, Finke EH (1960) Embedding in epoxy resins for ultrathin sectioning in electron microscopy. Stain Technol 35:313-325

Rojik I, Nemcsok J, Boross L (1983) Morphological and biochemical studies on liver, kidney and gill of fishes affected by pesticides. Acta Biol Hung 34:81-92

Rutschke E, Brozio F (1974) Bemerkungen zur Substruktur der Leber des Karpfens (Cyprinus carpio L.). Z MikroskAnat Forsch 88:745-758

Sachs L (1984) Angewandte Statistik. Springer, Berlin

Sastry KV, Siddiqui AA (1982) Effect of endosulfan and quinalphos on intestinal absorption of glucose in the freshwater murrel, Channa punctatus. Toxicol Lett 12 $289-293$

Sastry KV, Siddiqui AA (1983) Metabolic changes in the snake head fish Channa punctatus chronically exposed to endosulfan. Water Air Soil Pollut 19:133-142

Schimmel SC, Patrick JM, Wilson AJ (1977) Acute toxicity and bioconcentration of endosulfan by estuarine animals In: Mayer FL, Hamelink JL. (eds) Aquatic toxicology and hazard evaluation. American Society for Testing and Materials, p 241-252

Schoettger RA (1970) Toxicology of Thiodan in several fishes and aquatic invertebrates. US Bur Sport Fish Wild Invest Fish Control 35:1-18

Schoor WP, Couch JA (1979) Correlation of mixed function oxidase activity with ultrastructural changes in the liver of a marine fish. Cancer Biochem Biophys 4:95-103

Sharma RM (1988) Elfect of endosulfan on adenosine triphosphate (ATPase) activity in liver, kidney, and muscles of Channa gachua. Bull Environ Contam Toxicol 41:417-423

Siddiqui MKJ, Anjum F, Quadri SSH (1987) Some metabolic changes induced by endosulfan in hepatic and extrahepatic tissues of rat. J Environ Sci Health 22B:553-564

Sindermann CJ (1984) Fish and environmental impact. Arch Fisch Wiss 35:125-160

Singh I (1964) A modification of the Masson-Hamperl method for staining of argentaffin cells. Anat Anz 115:81-82

Sinha N, Lal B, Singh TP (1991) Effect of endosulfan on thyroid physiology in the freshwater catfish, Clarias batrachus. Toxicology 67:187-197

Spurr AR (1969) A low viscosity embedding medium for electron microscopy. J Ultrastruct Res 26:31-43

Storch V, Welsch U, Schünke M, Wodtke E (1984) Einfluß von Temperatur und Nahrungsentzug auf die Hepatocyten von Cyprinus carpio (Cyprinidae, Teleostei). Zool Beitr NF 28:253-269

Stroband HWJ, Van den Meer H, Timmermanns LPH (1979) Regional functional differentiation in the gut of the grasscarp (Ctenopharyngodon idella Val.). Histochemistry 64: $235-249$

Sunderam RIM, Cheng DMH, Thompson GB (1992) Toxicity of endosulfan to native and introduced fish in Australia. Environ Toxicol Chem 11:1469-1476 
Tyagi SR, Singh Y, Srivastava PK, Kisra UK (1984) Induction of mixed function oxidase system by endosulfan in rats. Bull Environ Contam Toxicol 32:550-556

Tyagi SR, Sriram K, Narayan S, Misra UK (1985) Induction of cytochrome P-450 and phosphatidylcholine synthesis by endosulfan in liver of rats: effect of quality of dietary proteins. J Environ Sci Health 20B:651-664

Van Dyk LP, Greeff CG (1977) Endosulfan pollution of rivers and streams in the Loksop Dam cotton-growing area. Agrochemophysica 9:71-75

Verma SR, Rani S, Tonk IP, Dalela RC (1983) Pesticideinduced dysfunction in carbohydrate metabolism in three freshwater species. Environ Res 32:127-133

Verschueren K (1983) Handbook of environmental data on organic chemicals. Van Nostrand Reinhold, New York

Editorial responsibility: Otto Kinne (Managing Editor), Oldendorf/Luhe, Germany
Wall GJ, Wilding LP, Smeck NE (1978) Physical, chemical, and mineralogical properties of fluvial unconsolidated bottom sediments in Northwestern Ohio. J Environ Qual 7: 319-325

Wegmann RCC, Greve PA (1978) Organochlorines, choline esterase inhibitors and aromatic amines in Dutch water samples, September 1969-December 1975. Pestic Monit J 12:149-162

Weibel ER (1979) Stereological methods, Vol 1. Academic Press, New York

Weibel ER, Stäubli W, Gnägi HR, Hess FA (1969) Correlated morphometric and biochemical studies on the liver cell. I. Morphometric model, stereologic methods and normal morphometric data for rat liver. J Cell Biol 42: $68-91$

Revised version submitted and accepted: April 30, 1999 Proofs received from author(s): May 21, 1999 